Dzieje Najnowsze, Rocznik L - 2018, 4

PL ISSN 0419-8824

Krzysztof Jasiewicz

Instytut Studiów Politycznych Polskiej Akademii Nauk

\title{
Nieznany epizod II wojny światowej. Sowiecka okupacja Suwalszczyzny 24 IX - 6 X 1939 r. jako studium przypadku
}

\begin{abstract}
Abstrakt: Okupacyjno-wojenna historia Suwałk i Suwalszczyzny kojarzona jest wyłącznie z agresją niemiecką i późniejszą przynależnością do III Rzeszy. Pierwotnie owe terytorium znalazło się jednak pod okupacją sowiecką. Tak stanowił pakt Ribbentrop-Mołotow z 23 VIII 1939 r. Artykuł opisuje działania militarne strony sowieckiej oraz postawy miejscowej ludności, zróżnicowanej pod względem etnicznym i konfesyjnym. W opisywanym regionie na początku wojny nie dochodziło do konfliktów charakterystycznych dla polskich Kresów Wschodnich, co umożliwia przeprowadzenie badań bez późniejszych naleciałości spowodowanych długotrwałą okupacją sowiecką.
\end{abstract}

Słowa kluczowe: Suwałki, Suwalszczyzna, sowiecka okupacja Suwalszczyzny 24 IX - 6 X 1939 r., konflikty narodowościowe, sowieckie działania militarne na Suwalszczyźnie we wrześniu 1939 r.

Abstract: The war and occupation history of Suwałki and Suwałki region is associated almost exclusively with the German aggression and the later annexation of this territory to the Third Reich. Initially, however, the area was under the Soviet occupation, according to the provisions of the Ribbentrop-Molotov Pact of 23 August 1939. The article describes military operations of the Soviets and attitudes of the local population, diverse both in terms of ethnicity and religion. At the beginning of the war there were no conflicts in the analysed region, characteristic of the Polish Eastern Frontiers, which allows us to conduct research with no later influences resulting from the long Soviet occupation.

Keyw ords: Suwałki, Suwałki region, Soviet occupation of Suwałki Region 24 September 6 October 1939, nationality conflicts, Soviet military operations in Suwałki region September 1939. 
Okupacyjno-wojenna historia Suwałk i Suwalszczyzny kojarzona jest wyłącznie z najazdem niemieckim i późniejszą przynależnością tego obszaru do III Rzeszy. Suwałki, przemianowane na Sudauen, cały przedwojenny powiat suwalski wraz z byłym sejneńskim i północna część powiatu augustowskiego na mocy rozporządzenia Hitlera z 8 X 1939 r. zostały włączone jako Kreis Sudauen do Prus Wschodnich w skład rejencji Gumbinnen (Głąbin) ${ }^{1}$, mimo iż pierwotnie sowiecko-niemiecki pakt o nieagresji wraz z tajnym protokołem, podpisany w Moskwie 23 VIII 1939 r. przez Ribbentropa i Mołotowa, określający strefy wpływów między układającymi się stronami, stanowił inaczej. $\mathrm{Na}$ ziemiach polskich rozgraniczenie stref wpływów (de facto tożsame z tzw. linią demarkacyjna) biegło bowiem wzdłuż linii rzek: Pisy (wypływająca z jeziora Roś [wówczas w Prusach Wschodnich]), Narwi, Wisły, Sanu (aż do źródeł w Bieszczadach), pozostawiając Suwalszczyznę we władaniu ZSRS². Jednak rozwój wydarzeń spowodował korektę pierwotnych ustaleń (i granic) i Sowieci oddali Niemcom ten obszar. Stało się to na mocy zawartego 28 IX 1939 r. w Moskwie porozumienia między Niemcami a ZSRR o przyjaźni i granicach ${ }^{3}$. Zwraca uwage skrajna hipokryzja dokumentacji sowieckiej. Czytamy w niej bowiem:

Z nastaniem świtu 17 września [1939 r.] armie Frontu Białoruskiego przechodzą do natarcia z zadaniem wsparcia powstańców robotników i chłopów Białorusi i Polski w zrzuceniu jarzma obszarników i kapitalistów i niedopuszczenia do zdobycia terytorium Zachodniej Białorusi przez Niemcy. Najbliższe zadanie Frontu - zniszczyć i wziąć do niewoli siły zbrojne Polski, operujące na wschód od granicy litewskiej i linii Grodno-Kobryń 4 .

Propagandową bzdurą była podana w rozkazie bojowym nr 01 informacja o rzekomych powstaniach robotników i chłopów. Kontrwywiad polski, jak się wydaje, nie miał najlepszego rozpoznania w zakresie działalności sowieckich służb specjalnych na terenach polskich ${ }^{5}$. Poza akcjami dywersyjnymi,

${ }^{1}$ K. Skłodowski, Wojna i okupacja, w: Suwatki. Miasto nad Czarna Hańcza, red. J. Kopciał, Suwałki 2005, s. 447.

${ }^{2}$ Agresja sowiecka na Polskę w świetle dokumentów 17 września 1939, t. I: Geneza i skutki agresji, wybór i oprac. Cz. Grzelak, S. Jaczyński, E. Kozłowski, Warszawa 1994, dok. 40-41, s. 87-90.

${ }^{3}$ K. Skłodowski, Wojna i okupacja..., s. 447; Traktat o przyjaźni i granicy między ZSRR a Niemcami z 28 IX 1939 oraz Protokoły dodatkowe do traktatu o przyjaźni i granicy między ZSRR a Niemcami z 28 IX 1939, w: Katyń. Dokumenty zbrodni, red. i oprac. nauk. W. Materski, B. Woszczyński, N.S. Lebiediewa, N.A. Pietrosowa i in., t. I: Jeńcy nie wypowiedzianej wojny, Warszawa 1995, dok. 25-26, s. 109-113.

${ }^{4}$ Rozkaz bojowy nr 01 Sztabu Frontu Białoruskiego Armii Czerwonej, w: Katyń..., t. I, dok. 3, s. $67-70$.

${ }^{5} \mathrm{Na} 200$ szpiegów zdemaskowanych w 1938 r. tylko ok. 10\% przypadło na wywiad sowiecki (agenci narodowości żydowskiej, białoruskiej, kilku ukraińskiej i polskiej), co zapewne nie odpowiadało rzeczywistej liczbie osób z nim współpracujących. Rosyjskie Państwowe Archiwum 
niewykluczone, że inspirowanymi przez Sowietów i działalnością tzw. band na wskazanym terytorium tzw. Zachodniej Białorusi czy Suwalszczyzny, nie pojawiły się żadne symptomy rewolucji, a szczytem tej hipokryzji było sformułowanie o niedopuszczeniu „do zdobycia terytorium Zachodniej Białorusi przez Niemcy", co wszak nie stanowiło przedmiotu sporu między zaborcami ${ }^{6}$.

Sowiecko-niemieckie umowy z 1939 r. stały się punktem zwrotnym w dziejach kontynentu, który w krótkim czasie pogrążył się w kolejnej wielkiej wojnie. Z perspektywy 75 lat, w naszej świadomości zbiorowej, tamten podział na strefy wpływów, obok wymiaru geograficznego, otrzymał wymiar czasowy, układając się w logiczny ciag różnej wielkości wojen (kampanii), począwszy od kampanii wrześniowej w Polsce, poprzez sowiecką agresję na Finlandię w 1939 r., zwana wojną zimowa, niemiecki atak na Danię, Norwegię, Belgię, Holandię, Luksemburg, Francję i nieudaną wojnę powietrzna z Wielka Brytanią w $1940 \mathrm{r}$. W tym samym roku zbiegło się to z sowiecka agresja na państwa bałtyckie i aneksja Besarabii i Bukowiny.

Jednak ów nowy podział świata nie dokonywał się w ściśle zaplanowanej chronologii, a podboje i towarzyszące im zmiany granic państwowych czy stref wpływów były procesem in statu nascendi. Wtedy mogły się jeszcze wydarzyć różne rzeczy i zaistnieć inne warianty.

Dynamikę tego procesu kształtowały gwałtownie rozwijające się zbrojenia oraz zwiększanie stanu rozwinięcia własnych sił zbrojnych; wojnę czuć było niemal w powietrzu, zwłaszcza w poprzedzajacych ją miesiącach. Sowieci chcąc zwiększyć tempo zbrojeń, sięgnęli na wielką skalę do zasobu więźniów (co oczywiście wcześniej też robiono). Zbrojeń dotyczyły decyzje podjęte przez Komitet Centralny Wszechzwiązkowej Komunistycznej Partii (bolszewików) i Radę Komisarzy Ludowych ZSRS z 11-17 VI 1939 r. NKWD otrzymał polecenie, aby w czerwcu-lipcu 1939 r. przekazać z więzień lub łagrów 120 tys. więźniów do prac na rzecz obronności państwa. Akcja przebiegała z zakłóceniami, gdyż do 8 VIII 1939 r. nie udało się przetransportować, z braku wagonów, jeszcze 44 tys. więźniów?

Wojskowe w Moskwie (dalej: RGWA), Archiwum Specjalne, f. 308, op. 7, d. 66, Statystyka spraw szpiegowskich zlikwidowanych w 1938 r., II Oddział Sztabu Głównego, Warszawa 1939, mps, k. 7-48 i n. Tymczasem sowieckie służby specjalne miewały się zupełnie dobrze i miały nieźle rozpoznane przedpole przyszłego teatru działań wojennych. Liczne dokumenty na ten temat: Organy gosudarstwiennoj biezopasnosti SSSR w Wielikoj Otieczestwiennoj wojnie, t. I: Nakanunie, Kniga pierwaja (nojabr' 1938 g. - diekabr' 1940 g.) i Kniga wtoraja (1 janwarja - 21 ijunja 1941 g.), Moskwa 1995; zob. też: Dokumienty wnieszniej politiki 1940 - 22 ijunja 1941, red. G.E. Mamiedow i in., Moskwa 1998.

${ }^{6}$ Rozkaz bojowy nr 01 Sztabu Frontu Białoruskiego Armii Czerwonej, w: Katyń..., t. I, dok. 3, s. 67-70.

${ }^{7}$ Państwowe Archiwum Federacji Rosyjskiej w Moskwie (dalej: GARF), f. 5446, op. 23a, d. 18, Pismo Nr 3411/b Ludowego Komisarza Spraw Wewnętrznych ZSRR Ł. Berii do Przewodniczącego Rady Komisarzy Ludowych ZSRR W. Mołotowa z 9 VIII 1939 r., k. 40. 
W ZSRS trwały też wyjątkowo intensywne studia nad różnymi operacjami wojskowymi z czasów I wojny światowej i wcześniejszymi - rosyjskiej wojny domowej, niedawnej wojny w Hiszpanii itd. ${ }^{8}$

Sowieci z żelazną konsekwencją zbierali i analizowali materiały dotyczące wszelkich konfliktów zbrojnych, działalności różnych partyzantek i życia polityczno-społecznego ościennych krajów. Zanim sami włączyli się do wojny totalnej w 1941 r., dość trafnie wyciagali wnioski z rozgrywających się u ich granic konfliktów. Szczególnie uważnie przyglądali się niemieckiej machinie wojennej i pod tym katem zrealizowali kilka ważnych gier operacyjno-sztabowych.

I tak podsumowujac znaczenie gry przeprowadzonej w dniach 23-31 XII 1940 r. w kontekście doświadczeń wojny - jak określał to dokument pt. „Zachodnioeuropejska wojna lat 1939-1940” - marszałek Siemion K. Timoszenko stwierdził: „Przede wszystkim trzeba podkreślić, że zmasowane użycie takich środków, jak czołgi i bombowce nurkujące, w połączeniu z wojskami zmotoryzowanymi i motocyklowymi, we współdziałaniu ze spadochronowymi i wysadzanymi desantami, i masowym użyciu lotnictwa - zapewniło, oprócz innych przyczyn, wysokie tempo i siłę współczesnego operacyjnego natarcia"9.

Związek Sowiecki na przełomie września i października 1939 r. - co może być dobra egzemplifikacją tezy o procesach in statu nascendi-przygotowywał desant morski na Estonię przy użyciu utworzonego 25/26 IX 1939 r. Oddziału Specjalnego Przeznaczenia Floty Bałtyckiej na mocy polecenia Rady Wojennej Floty Bałtyckiej ${ }^{10}$. Operacja ta nie doszła do skutku. Oprócz przyczyn obiektywnych (bardzo złe warunki pogodowe - sztorm na Bałtyku utrudniający przeprowadzenie takiej operacji) niewykluczone, że Stalin, który bardzo dbał o pozory (wszak nieprzypadkowo uderzając na Polskę 17 września, rozpowszechniał wersję wzięcia w obronę „braci Białorusinów i Ukraińców"), zrezygnował z tego pomysłu w obawie o międzynarodowe jego reperkusje. Zauważmy, że po napadzie na Finlandię ZSRS został wyrzucony z Ligi Narodów. Chociaż kierownictwo sowieckie miało świadomość, że ani Francja, ani Anglia nie włączą się aktywnie do wojny i wydarzenia militarne w Europie Środkowej i Wschodniej mogą rozwijać się niemal bezkarnie ${ }^{11}$.

${ }^{8}$ RGWA, f. 25888 , op. 15 , d. 458 , Plan przepracowania operacyjno-taktycznych i wojenno-historycznych tematów przez kadrę dowódczą i polityczną Leningradzkiego Okręgu Wojskowego w 1939 r., k. 1.

${ }^{9}$ Armia Czerwona w latach 1940-1941 (Materiaty z posiedzenia Gtównej Rady Wojennej $i$ wyższej kadry dowódczej Armii Czerwonej $w$ dniach 23-31 grudnia 1940 roku), oprac. J.R. Budziński, Cz. Grzelak, Z. Matuszak, Warszawa 2007, s. 201. Zob. też: Cz. Grzelak, Armia Stalina 1939-1941. Zbrojne ramię polityki ZSRS, Kielce-Warszawa 2010.

${ }_{10}$ Centralne Państwowe Archiwum Marynarki Wojennej w Sankt Petersburgu (Centralnyj Gosudarstwiennyj Archiw Wojenno-Morskogo Fłota), f. P-92, op. 2, d. 458, Materiały dotyczace przygotowań operacji desantowej Oddziału Specjalnego Przeznaczenia Floty Bałtyckiej 25.9. - 14.10.1939, k. 2 i n.

11 Wojennaja razwiedka informirujet. Dokumienty razwieduprawlenija Krasnoj Armii, janwar’ 1939 - ijun’ 1941 g., oprac. W.A. Gawriłow, Moskwa 2008, s. 120-121 - informacja 
Być może decydowały też względy techniczne. Flota Bałtycka nie dysponowała dobrym sprzętem do wysadzenia desantu i wkrótce kierownictwo ludowego komisariatu marynarki wojennej podjęło starania o szybkie wzmocnienie jej potencjału. W styczniu-lutym 1940 r. Komitet Obrony zdecydował "O budowie barek desantowych dla Morza Bałtyckiego"12.

Chodziło o zbudowanie 4 barek z własnym napędem, a raczej zmodernizowanie nowo budowanych barek desantowych w stoczni w Stalingradzie (stopień zaawansowania ich budowy wynosił od $78,3 \%$ do $86,4 \%$ ) i dostarczenie ich do Leningradu w terminie do $1 \mathrm{~V} 1940 \mathrm{r}^{13}{ }^{13}$,w celu zabezpieczenia desantowych operacji na Morzu Bałtyckim środkami specjalnymi"14. Pierwotnie były one przeznaczone dla Teatru Amurskiego i miały być wykończone w 1941 r. O złej sytuacji Floty Bałtyckiej w zakresie prowadzenia operacji desantowych informował czynniki rządowe narkom marynarki wojennej, adm. Nikołaj G. Kuzniecow już w styczniu 1940 r.: „Trzeba okres zalegania lodu wykorzystać dla zmiany tego stanu rzeczy, by wraz z wznowieniem nawigacji flota była w pełnej gotowości do prowadzenia operacji desantowych"15. Ostatecznie Flota Bałtycka powinna otrzymać owe 4 barki uzbrojone w gniazda karabinów maszynowych kalibru $12,7 \mathrm{~mm}$ (po 4 gniazda na barkę) i po 6 radiostacji na każdą barkę. Każda z nich miała wyporność $538 \mathrm{t}$ i pojemność 700 żołnierzy z pełnym uzbrojeniem i techniką (19 dział lub 5 czołgów) ${ }^{16}$. W kwietniu 1940 r. adm. Kuzniecow informował Stalina i Mołotowa o konieczności znacznego wzmocnienia sił artylerii nabrzeżnej w celu wsparcia floty na Bałtyku, wyposażenia jej w miny, rozbudowy infrastruktury kolejowej i telefonicznej pod katem potrzeb floty, bo nowa sytuacja na Bałtyku wymagała reorganizacji sił morskich, które oprócz zadań obronnych „muszą mieć zdolność do samodzielnych operacji w oddaleniu od baz"17. Sprawa desantu znalazła też swoje odzwierciedlenie w prowadzonych manewrach przez wojska Leningradzkiego Okręgu Wojskowego. Ćwiczono kilka wariantów operacji desantowej z udziałem floty i lotnictwa ${ }^{18}$.

wywiadowcza pochodząca od kombriga Czernyj'ego, wojskowego attaché sowieckiej ambasady w Londynie z 13 VIII 1939: „Nie należy się spodziewać aktywnego włączenia się Anglii i Francji [w razie wybuchu wojny] a konflikt będzie miał charakter lokalny”.

12 GARF, f. 8418 ss, op. 24, d. 1130, Pismo „O budowie barek desantowych dla morza Bałtyckiego" z 8 II 1940 r., k. 1.

${ }^{13}$ Ibidem, Postanowienia Komitetu Obrony nr 21 ss z 9 I 1940 r., k. 4; ibidem, Notatka dla tow. Wozniesienskiego N.A. z 26 I 1940 od narkoma marynarki wojennej Kuzniecowa N.G., k. 4.

${ }^{14}$ Ibidem, Notatka dla tow. Wozniesienskiego..., k. 4.

${ }^{15}$ Ibidem, Pismo nr 282 ss z 24 I 1940 flagmana floty II rangi narkoma marynarki wojennej ZSRR N.G. Kuzniecowa do Rady Komisarzy Ludowych na ręce W. Mołotowa, k. 5.

${ }^{16}$ Ibidem.

${ }^{17}$ Ibidem, d. 1080, k. 1-7, Postanowienie nr 267 ss Komitetu Obrony przy RKL ZSRR z 20 VI 1940.

${ }_{18}$ RGWA, f. 25888, op. 6, d. 411, Wypis z planu operacyjno-taktycznych ćwiczeń lotnictwa wojskowego i floty Leningradzkiego Okręgu Wojskowego w okresie letnim 1940, k. 22. 
Na pierwszy rzut oka (ale tylko na pierwszy) Suwalszczyzna nie stanowiła nadzwyczajnej zdobyczy dla żadnej ze stron. Główne miasto regionu powiatowe Suwałki liczyły przed wojną 22120 mieszkańców (dane z 1937 r.; w 1931 r. - 21 826) i były typowym miastem Polski B ${ }^{19}$. Jego najbardziej charakterystyczna cechę stanowiło posiadanie jednego z największych w Polsce garnizonów. W mieście stale stacjonowało ok. 6 tys. żołnierzy ${ }^{20}$.

W latach dziewięćdziesiątych XX w. grupa historyków i archiwistów Rosyjskiego Państwowego Archiwum Wojskowego w Moskwie pod kierownictwem gen. mjr. Władimira Antonowicza Zołotarjewa przeprowadziła wszechstronna analize gier operacyjno-strategicznych organizowanych w latach 1940-1941 przez dowództwo sowieckie, podczas których ćwiczono różne warianty ataku niemieckiego na ZSRS i własne działania obronno-zaczepne. Jednym z wariantów takiego potencjalnego ataku niemieckiego - i to zostało wcześniej zauważone i przećwiczone w jednej z gier przez sowieckich sztabowców - było uderzenie niemieckie wyprowadzone z rejonu Suwałk i Prus Wschodnich oraz Brześcia na kierunku Baranowicze, które powodowało okrążenie wojsk

Dokument z kwietnia 1940 r. przewidywał trenowanie kilku wariantów desantu, m.in. w sierpniu dokonanie zwykłego desantu na przeciwnika, we wrześniu - operacja desantowa z przeciwuderzeniem silnego przeciwnika.

19 A. Matusiewicz, Lata międzywojenne, w: Suwatki. Miasto..., s. 322-323 i n.

${ }^{20}$ K. Skłodowski, Wojna i okupacja..., s. 409 - liczba 6 tys. stoi w sprzeczności z innymi danymi i zapewne różnice biorą się z faktu, iż jednostki wojskowe mają różne stany w okresie pokoju, jak i u progu spodziewanej wojny. I tak np. według stanu na $1933 \mathrm{r}$. w garnizonie suwalskim stacjonowało 3183 żołnierzy, z tego 132 Żydów (4,1\%), najwięcej w 41 pp - 76, w 2 Pułku Ułanów - 16, w 3 Pułku Szwoleżerów - 25, w 4 DAK - 15; wśród żołnierzy byli także Białorusini (najliczniejsi po Polakach), Rosjanie, Litwini, Niemcy; w całym DOK III wskaźnik Żydów w wojsku wynosił 5,26\%. K. Skłodowski, Stużba duszpasterska w garnizonie Suwatki 1921-1939, „Rocznik Augustowsko-Suwalski” 2012, t. XII, s. 59-76. Do tego dochodzą ewentualne przemieszczenia części pododdziałów w ramach zmian dyslokacji w okręgu (w przypadku garnizonu suwalskiego - DOK III w Grodnie). Dodajmy, że tak liczne wojsko brało się w pewnej mierze z przypadku (chociaż też z dobrego położenia miasta przy granicach niemieckiej i litewskiej), bowiem Suwałki odziedziczyły po rosyjskim zaborcy trzy kompleksy koszarowe, w których przed I wojną światowa stacjonowały: 2 Lejbdragoński Pskowski Pułk Imperatorowej Marii Fiodorownej, 2 Lejbhuzarski Pawłogradzki Pułk Imperatora Aleksandra III i 2 Dywizjon Artylerii Konnej ze składu 2 Dywizji Kawalerii oraz 17, 18, 19 i 20 Pułk Strzelecki i 5 Strzelecki Dywizjon Artylerii z 5 Brygady Strzeleckiej. W Suwałkach znajdowały się także sztaby i dowództwa 2 Dywizji Kawalerii, 5 Brygady Strzeleckiej oraz 1 i 2 Brygady Kawalerii. Stacjonowanie wojsk rosyjskich wsparte było od 1899 r. posiadaniem do dyspozycji linii kolejowej Orany-Olita (tzw. Nadniemeńskiej), która wybiegała półkolem z głównej linii kolejowej Królestwa Polskiego, Drogi Żelaznej Warszawsko-Petersburskiej, dając armii carskiej znakomite możliwości ofensywnego manewru operacyjnego na obszarze Prus Wschodnich. Na ten temat zob. K. Jasiewicz, Militarne i ekonomiczne aspekty $w$ budowie $i$ eksploatacji dróg żelaznych $w$ Królestwie Polskim w latach 1835-1914, „Studia Historyczne” R. XXIII, 1980, z. 2 (89), s. 191-207; idem, Wykorzystanie kolei do celów militarnych (1830-1914), „Eksploatacja Kolei” R. V (XXIX), 1982, nr 4, s. 108-110. 
sowieckich w rejonie Białegostoku (w tzw. występie białostockim), co się faktycznie wydarzyło podczas niemieckiego ataku w czerwcu $1941 \mathrm{r}$. W naturze było to jednak uderzenie pomocnicze, którego cel sprowadzał się do odwrócenia uwagi Sowietów od głównego uderzenia niemieckiego prowadzonego na południe od Brześcia ${ }^{21}$.

W przededniu II wojny światowej w Suwałkach stacjonowały: 3 Pułk Szwoleżerów Mazowieckich im. płk. Jana Hipolita Kozietulskiego (w b. koszarach lejbhuzarskich przy szosie sejneńskiej na wschodzie miasta), 2 Pułk Ułanów Grochowskich im. gen. Józefa Dwernickiego (ulokowany na północy miasta w b. koszarach lejbdragońskich), 11 Szwadron Łaczności Suwalskiej Brygady Kawalerii oraz 41 Pułk Piechoty im. Marszałka Józefa Piłsudskiego, 4 Dywizjon Artylerii Konnej i 1 dywizjon 29 Pułku Artylerii Lekkiej (wszystkie $\mathrm{w}$ b. koszarach pułków strzeleckich przy szosie augustowskiej na południu miasta). Na zachodzie miasta $\mathrm{w}$ b. budynkach wojskowych przy drodze do Filipowa stacjonował 29 Batalion Korpusu Ochrony Pogranicza „Suwałki” (zajmował także jeden budynek mieszkalny na terenie koszar 2 Pułku Ułanów). Dowództwo i sztab Suwalskiej Brygady Kawalerii oraz służby i oddziały pomocnicze znalazły miejsce w gmachu Sądu Okręgowego przy ul. Kościuszki $69^{22}$. Rozwojem sytuacji szczególnie wydawali się zaniepokojeni Żydzi, także ci suwalscy i z najbliższej okolicy, żyjący jakby na uboczu świata ${ }^{23}$. Jak pisze Jecheskel Berlzon, Żydzi suwalscy w 1939 r. nie chcieli wierzyć, że może wybuchnąć kolejna wojna ${ }^{24}$. Jednak już od wiosny 1939 r. w mieście był odczuwalny strach przed jej wybuchem, a jej nadchodzenie zwiastowały także pewne symptomy. I tak np. co roku podczas Pesach 500-600 żołnierzy żydowskich stacjonujących - wedle Berlzona - w jednostkach garnizonu suwalskiego bez problemu mogło opuścić koszary i udać się na wieczerzę sederową i spędzić 2 dni ze swoimi, modląc się itp. Na Pesach w 1939 r. dowódca zwolnił żołnierzy żydowskich tylko na kilka godzin, tłumacząc rabinowi, że: „Musimy być gotowi”. Elul (chodzi tutaj o koniec sierpnia) upływał w uczuciach strachu i nadziei ${ }^{25}$.

Garnizon i miasto nie zostały zaskoczone wybuchem wojny. Od 24 sierpnia trwała mobilizacja alarmowa, a 31 sierpnia w mieście pojawiły się plakaty informujące o powszechnej mobilizacji; cały czas do macierzystych jednostek

${ }^{21}$ Armia Czerwona w latach 1940-1941..., s. 236-239.

${ }^{22}$ S. Buczyński, Suwalszczyzna 1939-1944, Warszawa 1991, s. 10; Wykaz okregów korpusów, dywizji, brygad i putków Wojska Polskiego na stopie pokojowej i miejsc ich stacjonowania, w: J. Tucholski, Mord w Katyniu. Kozielsk-Ostaszków-Starobielsk - lista ofiar, Warszawa 1991, s. 549-551; K. Skłodowski, Wojna i okupacja..., s. 409-419 i n.

${ }_{23}$ Sefer kehilat Suvalk u-benotehah (Jewish community book Suwalk and vicinity), ed. Y. Alroi, Y. Chrust, Tel Aviv 1989; Jisker-buch Suwalk un di arumike sztetlech: Baklerawe, Wiżan, Jelinewe, Sejni, Punsk, Pszerasle, Filipowe, Krasnepolie, Rack, ed. B. Kohen, New York 1961.

${ }_{24}$ J. Berlzon, Churbn Suwatk [Zagłada Suwatk], w: Jisker-buch Suwalk..., s. 595.

${ }^{25}$ Ibidem, s. 596. 
przybywali rekruci. Wywołało to trochę paniki wśród miejscowych Żydów. Wielu z nich opuściło miasto i uciekło do głównych miast w Polsce i miejscowości w pobliżu rosyjskiej granicy. Pozostali w mieście ludzie biedni, starcy, chorzy i klasa średnia oraz ci, co nie mieli sił uciekać ${ }^{26}$. Wzorując się na doświadczeniach I wojny, jak i walk późniejszych o niepodległość, w mieście powołano komitet obywatelski. Jego pełny skład i okoliczności powstania nie sa dokładnie znane, wiadomo jedynie, że weszli weń ówcześnie najbardziej poważani obywatele Suwałk, tacy choćby jak prezydent miasta Walerian Łopatta, Melania Wietcka - sekretarz Zarządu Miejskiego, Czesław Pstrokoński - wieloletni naczelnik straży ogniowej w Suwałkach, mecenas Zygmunt Kadłubowski - poseł na sejm w latach 1922-1928 i inni. Na obszarze Suwalszczyzny nie doszło do walk polsko-niemieckich. 2 września samoloty niemieckie zbombardowały jedynie dworzec kolejowy i koszary - zginęło 2 żołnierzy i 2 cywili, 10 osób raniono ${ }^{27}$. Ten sam nalot we wspomnieniach żydowskich zachował się $\mathrm{w}$ wymiarze apokaliptycznym. W tej narracji miasto mocno bombardowano, szczególnie koszary wojskowe i dworzec, było wiele ofiar. Również długotrwałość nalotów ma zupełnie inną skalę. „Niemalże każdego dnia były zrzucane niemieckie bomby, ale nie widziano ani jednego niemieckiego żołnierza" ${ }^{28}$.

3 września społeczność miejska, w tym Żydzi, z entuzjazmem przyjęła wieść o wypowiedzeniu wojny Niemcom przez Anglię i Francję. Na głównej ulicy - Kościuszki pojawiły się tłumy wiwatujących starozakonnych. W nocy z 4 na 5 września Suwałki i Suwalszczyznę opuściły obecne tam jeszcze oddziały Suwalskiej Brygady Kawalerii. W tym samym czasie rozpoczęto dość chaotyczną ewakuację bądź likwidację obiektów i mienia o charakterze strategicznym. Część wojsk garnizonu suwalskiego trafiła aż pod Warszawę, broniąc stolicy przed Niemcami ${ }^{29}$.

Po opuszczeniu Suwałk przez wojsko i policję zapanował chaos i znacząco pogorszyło się bezpieczeństwo w mieście, spowodowane - zdaniem osób zdajacych relacje - m.in. pojawieniem się utworzonej spontanicznie milicji żydowskiej, chodzącej z czerwonymi opaskami, która zajęła się poszukiwaniami osób związanych przed wojną z endecją i jak to ujął jeden ze świadków, „było wówczas niebezpiecznie” ${ }^{30}$. Za wojskiem ewakuowały się także w tym samym kierunku, do Grodna, nieliczne zakłady przemysłowe, m.in. położony ok. $10 \mathrm{~km}$ na południowy wschód od Suwałk tartak w Płocicznie ${ }^{31}$.

${ }^{26}$ K. Skłodowski, Wojna i okupacja..., s. 442; J. Berlzon, op. cit., s. 597.

${ }^{27}$ K. Skłodowski, Wojna i okupacja..., s. 443-444.

28 J. Berlzon, op. cit., s. 598. Rzucająca się w oczy pewna skłonność do przesady w źródle żydowskim może owocować obniżeniem jego wiarygodności.

${ }^{29}$ S. Buczyński, op. cit., s. 17 i n. Szerzej zob. K. Skłodowski, Wojna i okupacja..., s. 442-444.

${ }^{30}$ Rel. Tadeusz Żochowski z Suwałk, ur. 1922, w 1939 uczeń gimnazjum, z 15 VII 2010; w zbiorach autora.

${ }^{31}$ Zob. np.: Archiwum Wschodnie (dalej: AW), I/229, rel. Antoni Gwiazdowski, passim. 
Proces powstawania milicji żydowskiej (samoobrony) zupełnie inaczej relacjonują źródła żydowskie. W mieście zapanował strach, ludzie ukrywali się w piwnicach przed bombami. Wśród Żydów zawiązał się mały komitet. Jednym z jego zmartwień była sprawa żydowskich więźniów. W końcu postanowiono się wstawić za nimi, żeby zostali uwolnieni. Członkowie komitetu (to niejasne) chodzili od celi do celi, aby wyciagnąć więźniów Żydów. Uwolnić ich też zgodził się komendant więzienia po wysłuchaniu przedstawicieli komitetu: rabina i doktora Staropolskiego. Następnie miasto opuścił doktor Staropolski. W tym czasie odbywało się też święto Rosz ha-Szana (żydowski Nowy Rok). Zastanawiano się, czy na święta powinna być otwarta wielka synagoga, czy to będzie bezpieczne itd. Strach się wzmógł, kiedy nastapiła mobilizacja i nadszedł czas pożegnań z powołanymi do wojska.

Ostatecznie postanowiono, aby synagoga była otwarta na Rosz ha-Szana, bo zamknięcie jej spotęgowałoby tylko uczucie niepokoju wśród Żydów. Sytuacja się pogorszyła w Szabat Szuwa po Rosz ha-Szana, kiedy rano nagle Wojsko Polskie opuściło miasto. W ciagu dnia podobnie postapiły policja i poczta. „[...] i to był najlepszy znak, że Polska oddała Suwałki” - konkluduje źródło. Razem z tym zaczęły rozpowszechniać się z różnych stron wiadomości, że sowiecka armia przekroczyła polska granicę, że weszła już do Baranowicz, Wołkowyska, Lidy i zbliża się do Grodna, Augustowa, Suwałk. Zasłyszano też w radiu o podziale Polski pomiędzy ZSRS a Niemcami. „Czy Suwałki znajdą się w sowieckiej części?” - martwili się suwalscy Żydzi. W związku z możliwością ekscesów antyżydowskich i pogłoskami, że do takowych incydentów dochodzi, stało się ważne utworzenie żydowskiej straży w mieście. Postanowiono o tym podczas zebrania $\mathrm{w}$ domu rabina. Przywódcami utworzonej straży zostali: drukarz B. Genio, Grichendler, Kalman Seglman, sekretarz związków rzemieślników Abraham Ber Cimerman, piekarz Chackl Zilbersztajn, Mosze Kalinksi i inni. Na Jom Kipur straż wzmocniono. Część została umieszczona w kwartale miasta zwanym „Dołek”, inną rozlokowano w pobliżu cmentarza (żydowskiego). Pozostali członkowie straży czuwali w okolicy żydowskich mieszkań oraz synagog i domów modlitwy. Pojawiły się pogłoski, które straż przekazała rabinowi, że chuligani znajduja się w drodze pomiędzy Augustowem a Suwałkami, żeby zrobić pogrom (niewykluczone, że tak nazwano powracająca do Suwałk nieliczną grupę policjantów i żołnierzy, o czym dalej). Rabin po długich rozmyślaniach postanowił, aby część straży udała się na szosę augustowska, skąd moga przybyć chuligani; ponadto, że trzeba skontaktować się z miejscowymi łobuzami i chuliganami, którzy zapewne maja kontakt ze swoimi „towarzyszami” i przekazać im informację, że Żydzi sa gotowi oddać dużą sumę pieniędzy i kosztowności, aby ci zapobiegli przedostaniu się obcych „pogromszczyków” do miasta. Ostatecznie postanowiono, by nie polegać na półświatku i wszyscy po wyjściu z synagogi udali się do domów, gdzie mieli się dobrze zamknąć. 
Noc była bezsenna. Nikt nie zmrużył oka. Straż żydowska została wzmocniona. Na żydowskich ulicach patrolowali młodzi strażnicy, którzy byli gotowi na wszystko. Szczególnie chronione były sierociniec, dom starców i szpital żydowski. Zamknięto też wielką synagogę, bejs midrasze i cmentarz. Noc, która ciagnęła się tak długo jak żydowskie wygnanie, minęła - i za dzień - nagle zaczęły się pojawiać pierwsze oddziały czerwonej armii $^{32}$.

Narracja żydowska współbrzmi z polska, jednak różni się od niej pod względem semantycznym i emocjonalnym. I tak w polskiej pojawiają się „«młodzi Żydziacy» [młodzi Żydzi] z czerwonymi opaskami [...], [a za ich sprawa] w mieście było wówczas niebezpiecznie”33, a u Berlzona - „młodzi strażnicy, którzy byli gotowi na wszystko" ${ }^{34}$. Meritum zapewne się zgadza.

Wydarzenia opisywane przez źródło żydowskie miały miejsce w przedziale od 5 do ok. 24 września lub między 17 a 24 września. Dodajmy, że po 17 września w opuszczonym przez władze i wojsko mieście z inicjatywy suwalskiego adwokata i społecznika Czesława Bonawentury Lutostańskiego została zorganizowana polska służba porządkowa (milicja) składająca się $\mathrm{z}$ ochotników, w tym miejscowych strażaków ${ }^{35}$. Nic nie wiadomo więcej o charakterze tej formacji, jej działalności i ewentualnych relacjach z milicja żydowską lub Żydami.

W rejonie północno-wschodniej Polski operowały związki taktyczne i operacyjne Frontu Białoruskiego. Front ten, utworzony poprzez rozwinięcie Białoruskiego Specjalnego Okręgu Wojskowego, składał się początkowo z 3 armii (3, 10 i 11 Armia) oraz 3 grup (związki operacyjne podobne do armii, względnie wielkie związki taktyczne): Grupy Połockiej, Grupy Mińskiej oraz Dzierżyńskiej Grupy Konno-Zmechanizowanej. Wojska lądowe Frontu były wspierane przez 3 grupy lotnictwa dysponującego pułkami, brygadami lub eskadrami wszystkich typów samolotów (myśliwce, bombowce, szturmowce i samoloty rozpoznawcze). Dzierżyńska Grupa Konno-Zmechanizowana, dowodzona przez komkora (dowódca korpusu) Iwana Wasiljewicza Bołdina, składała się z 5 Korpusu Piechoty (13 i 4 dywizje strzeleckie), 6 Korpusu Kawalerii (1, 4 i 11 dywizje kawalerii) i 15 Korpusu Czołgów (2 i 27 brygady czołgów i 20 Brygada Piechoty Zmotoryzowanej) oraz 21 Brygady Czołgów ${ }^{36}$.

Na podstawie rozkazu Sztabu Frontu Białoruskiego nr 05/op i osobistego polecenia dowódcy Frontu komandarma II rangi (gen. płk.) Michaiła Prokofjewicza Kowalowa Dzierżyńska Grupa Konno-Zmechanizowana rozpoczęła 22 września operację likwidacji augustowskiego zgrupowania wojsk polskich oraz oczyszczania z resztek wojsk polskich rejonu: Wiżajny, Suwałki, Sejny.

\footnotetext{
${ }^{32}$ J. Berlzon, op. cit., s. 598-601.

${ }^{33}$ Rel. Tadeusz Żochowski.

${ }^{34}$ J. Berlzon, op. cit., s. 601 i n.

${ }^{35}$ K. Skłodowski, Wojna i okupacja..., s. 446.

${ }^{36}$ Rozkaz bojowy nr 01 Sztabu Frontu Białoruskiego Armii Czerwonej, w: Katyń..., t. I, dok. 3, s. 67-70.
} 
Dowodzili nią komkor Bołdin i członek Rady Wojennej Grupy, komisarz korpusowy S.P. Nikołajew. Przypomnijmy, że Dzierżyńska Grupa Konno-Zmechanizowana zgodnie z rozkazem $\mathrm{nr} 01$ miała nacierać na kierunku Nowogródek-Wołkowysk ${ }^{37}$.

W momencie rozpoczęcia operacji przez Sowietów samo miasto Suwałki i najbliższa okolica pozbawione były jakichkolwiek formacji zbrojnych, gdyż ostatnie resztki wojska wraz ze Strażą Graniczną i Policją Państwowa powiatu suwalskiego pod dowództwem komendanta powiatowego, nadkom. Józefa Makarewicza, 17 września wyruszyły do Grodna ${ }^{38}$. Po opuszczeniu Suwałk przez wojsko i policje zapanowały - wedle relacji polskich, o czym już wspomniałem - chaos i znaczące pogorszenie bezpieczeństwa w mieście ${ }^{39}$. Stan zagrożenia potęgował fakt wypuszczenia z miejscowego więzienia osób, które zaczęły „grasować po mieście” ${ }^{40}$.

Obraz ten jest więc zdecydowanie odmienny od źródła żydowskiego, zwłaszcza że trudno sobie wyobrazić sytuację, by zostawiono w celach pozostałych więźniów nie-Żydów. Gdyby zwolnienie dotyczyło jedynie więźniów Żydów, nasuwałaby się też interpretacja, że to właśnie oni „grasują po mieście". W tej sytuacji 21 lub 22 września do Suwałk z Grodna powróciła grupa 10 policjantów dla przywrócenia porządku, za nia przybyła grupka wojskowych, którzy po stoczeniu nierównego boju z Sowietami w Grodnie wracali do macierzystego garnizonu ${ }^{41}$.

Tymczasem Dzierżyńska Grupa Konno-Zmechanizowana rozpoczęła swój pochód. 23 września z rana jednostki 4 Dywizji Kawalerii ruszyły z rejonu Grodna i Białegostoku na Sejny przez Puszczę Augustowska. Wojska sowieckie miały za zadanie rozbicie resztek wojska polskich. Do takiego starcia doszło we wspomnianym rejonie $\mathrm{z}$ jednej strony pomiędzy zmechanizowanym pododdziałem 2 Brygady Czołgów pod dowództwem mjr. Czuwakina, zmotoryzowanym batalionem 101 Pułku Strzeleckiego, pododdziałem czołgów dowodzonym przez mjr. Bogdanowa i 4 Dywizja Kawalerii. Po stronie polskiej w bojach wzięły udział: pułk ochotników pod dowództwem płk. Dąmbrowskiego, 101 i 103 Pułk Kawalerii, samodzielne pododdziały i grupy 102 Pułku Kawalerii, 10 Pułku Zapasowego, 29 Batalionu Zapasowego, resztki 86, 41 i 42 Pułku Piechoty,

${ }^{37}$ Agresja sowiecka na Polskę.., t. I, s. 21; Rozkaz bojowy nr 01 Sztabu Frontu Białoruskiego Armii Czerwonej, w: Katyń..., t. I, dok. 3, s. 67-70.

${ }^{38}$ Instytut Polski i Muzeum Gen. Sikorskiego w Londynie (dalej: IPMS), LOT. A V 96/49, rel. Zdzisław Szych z 1 IV 1943, k. nlb.; relacjonista, ur. 6 IV 1911 r. w Kromołowie, pow. Zawiercie, wyznanie rzymskokatolickie, s. Jana i Bronisławy, ukończył 7 klas szkoły powszechnej, z zawodu ślusarz, ostatni przydział - 41 pp w Suwałkach, policjant w Suwałkach w momencie wybuchu wojny, a w chwili pisania relacji w Blackpool był w stopniu kaprala i podawał jako specjalność „żandarm” oraz stosunek do służby wojskowej jako „zawodowy”.

${ }^{39}$ Rel. Tadeusz Żochowski.

${ }^{40}$ IPMS, rel. Zdzisław Szych.

${ }^{41}$ Ibidem. 
żandarmeria grodzieńska i batalion Korpusu Ochrony Pogranicza ${ }^{42}$. Zwierzchnikiem sił polskich był dowódca OK III Grodno, gen. bryg. Józef Konstanty Olszyna-Wilczyński, który - według dokumentów sowieckich - zginą 22 IX 1939 w boju pod Sopoćkiniami k. Grodna, a według polskich ustaleń został tam zamordowany przez żołnierzy sowieckich ${ }^{43}$.

Inne pododdziały Dzierżyńskiej Grupy Konno-Zmechanizowanej - 109 Pułk Kawalerii i bateria artylerii otrzymały zadanie zajęcia Augustowa i skierowania się na Suwałki. 23 września 109 Pułk Kawalerii zajął Augustów, a następnego dnia o godz. 7.00 Suwałki, gdzie zakwaterował się w koszarach 2 Pułku Ułanów. 28 Pułk Pancerny wraz z reszta 4 Dywizji Kawalerii otrzymał zadanie przemieszczenia się na Giby i Sejny. W Gibach nastapiło połączenie z reszta 4 Dywizji Kawalerii i z końcem dnia 28 Pułk Pancerny zają Suwałki, a następnie wszedł w kontakt ze 109 Pułkiem Kawalerii. Pozostałe pododdziały 4 Dywizji Kawalerii doszły pod Suwałki ok. godz. 22.00 i zakwaterowały się w Sobolewie, $6 \mathrm{~km}$ na wschód od Suwałk. Następnego dnia od godz. 10.004 Dywizja przemieściła się o $30 \mathrm{~km}$ i skoncentrowała się w rejonie miejscowości Osowy, Góry, Kolnica, Białobrzegi, a sztab rozlokował się w okolicy Augustowa ${ }^{44}$.

Według zapisu znajdującego się w „Kronice parafialnej parafii św. Aleksandra w Suwałkach" wojska sowieckie wkroczyły do miasta 24 września, a opuściły je 6 października ${ }^{45}$.

Na Suwalszczyźnie nie odnotowano żadnych incydentów zbrojnych pomiędzy wojskiem sowieckim i polskim. Wobec informacji o ruchach wojsk sowieckich powracajacy z Grodna policjanci i żołnierze WP opuścili Suwałki 24 IV 1939 r. O godz. 12.30 na rozkaz Makarewicza przekroczyli granicę z Litwa na wysokości strażnicy Gromadziszki w powiecie suwalskim i zostali internowani w obozie Kalwaria ${ }^{46}$.

${ }^{42}$ RGWA, f. 35086, op. 1, d. 531, „Opisanije bojewych diejstwij 6-go Kazacz’jego kawalerijskogo korpusa im. tow. Stalina 10.9-25.10.39", k. 18-19.

${ }^{43}$ Ibidem, k. 18-19; T. Kryska-Karski, S. Żurakowski, Generałowie Polski niepodlegtej, Warszawa 1991, s. 139.

${ }^{44}$ RGWA, f. 35086, op. 1, d. 531, „Opisanije bojewych diejstwij...”, k. 18-20.

${ }^{45}$ Archiwum Parafii św. Aleksandra w Suwałkach - Kronika parafialna, rkps, s. nlb.: lakoniczny zapis brzmi: „24 września 1939 r. weszły do Suwałk wojska radzieckie, a 6 października t.r. po wyjściu wojsk rosyjskich Suwałki i Suwalszczyznę zajęła armia niemiecka”. Nie wiadomo, kto go dokonał (na ogół powinien to robić proboszcz). Ówczesnym proboszczem był ks. Bolesław Gumowski (1929-1957), ale nie udało mi się ustalić, kto zapisał tę informację i kiedy, bo nie można wykluczyć, że wpisy nie musiały być dokonywane na bieżąco, lecz post factum. Kolejny zapis pochodzi dopiero z... 7 IV 1940 r. i mowa w nim o aresztowaniu w Suwałkach 20 księży. Kwerenda pod kątem zawartości kronik parafialnych na terenie Suwalszczyzny przyniosła negatywne wyniki (Sejny, Krasnopol, Wiżajny, Raczki); brak też jakichkolwiek dokumentów/ informacji na ten temat w Archiwum Państwowym w Suwałkach.

${ }^{46}$ IPMS, rel. Zdzisław Szych. Dalsze losy relacjonisty były następujące: po kilku dniach pobytu w Kalwarii wraz z innymi został ulokowany w obozie w Kurczanach, stąd po 
Dalsze ruchy Armii Czerwonej prześledźmy szczegółowo, bo pokazuja one nam bardzo ciekawe zjawisko. 26 IX 1939 r. o godz. 10.00 do Suwałk wkroczyła zmotoryzowana grupa pod dowództwem kombryga Samokrutowa i wraz z nia grupa łączności pod dowództwem st. lejtnanta Kulczyckiego; były to pododdziały 3 Korpusu Kawaleryjskiego (należącego do innego związku operacyjnego - 11 Armii; 3 Korpus Kawaleryjski składał się z 7 i 36 Dywizji Kawalerii).

Wchodzaca w skład 3 Korpusu Kawaleryjskiego 7 Dywizja Kawalerii (zwracam uwagę, że to już przynależna do innego związku operacyjnego - 11 Armii - jednostka) 26 września o godz. 13.00 sformowała oddział złożony z 200 ludzi i $8 \mathrm{ckm}$, pułku czołgów pod dowództwem tow. Kudiura z zadaniem do godz. 15.0027 września zajęcia rejonu Sejny i Suwałki, aby zmienić oddziały 4 Dywizji Strzeleckiej (wchodzącej w skład Dzierżyńskiej Grupy Konno-Zmechanizowanej); pozostałe pododdziały 7 Dywizji Kawalerii kontynuowały 26 września marsz od godz. 13.00 do końca dnia, by skoncentrować się w rejonie miejscowości Choza, włączając w obszar działania Grodno, Ogrodniki i do końca następnego dnia (27 IX) weszły w rejon Sejny, Pradki, Kukle.

Kolejnego dnia (28 IX) oddział zmotoryzowany 7 Dywizji Kawalerii poruszał się po marszrucie Choza-Sopoćkinie-Sejny-Suwałki; część 7 Dywizji Kawalerii wraz ze sztabem dywizji skoncentrowała się do godz. 17.0030 września w Suwałkach, 80 Pułk Kawalerii z 7 Dywizji Kawalerii zatrzymał się w Sejnach, a pododdziały 36 Dywizji Kawalerii (to też 11 Armia) - w Augustowie. 1 października pododdziały 36 Dywizji Kawalerii skierowały się do Suwałk (102 Pułk Kawalerii) i przybyły tam o godz. 16.00, zmieniając tam 2 Dywizję Strzelecką (też ze składu 11 Armii), lecz tego samego dnia do godz. 20.00 cała 36 Dywizja Kawalerii z rejonu Suwałki, Serwy, Balinka, Grodno przemieściła się w rejon Krasne, Jagniaty, Bohatery, Lipsk, a ochronę granic zorganizowała 2 Dywizja Strzelecka, której jeden z pułków też 1 października przemieścił się z Suwałk via Augustów do Grodna, gdzie został skierowany do dyspozycji naczelnika garnizonu Grodno komdiwa Korobkowa. Sztab 3 Korpusu Kawaleryjskiego 2 października miał przebywać w Suwałkach, skąd przez

krótkim pobycie przewieziono ich do obozu dla internowanych w miejscowości Rokiszki (w majątku hr. Przeździeckiego). Panowały tam bardzo złe warunki, które spowodowały podjęcie strajku głodowego, popartego solidarnie przez oficerów zakwaterowanych w lepszych warunkach w pałacu. W trakcie protestu litewski żołnierz zastrzelił chorążego KOP z Klecka - Błaszczyka i dwóch innych żołnierzy, jednak strajk odniósł sukces, bo polscy internowani otrzymali lepsze zakwaterowanie. W obozie w Rokiszkach Szych przebywał cała zimę. 1 IV $1940 \mathrm{r}$. wszyscy zostali przewiezieni do obozu internowanych w Wiłkowyszkach, gdzie byli do 12 VII 1940. W tym dniu zostali załadowani do wagonów przez NKWD i przewiezieni do obozu w Kozielsku (tzw. Kozielsk II). W czerwcu 1941 r. przetransportowano ich na półwysep Kola (prawdopodobnie do miejscowości Ponoj), 18 VII 1941 przewieziono via Archangielsk do obozu w Suzdalu, gdzie 24 VIII 1941 Szych wstapił do Wojska Polskiego. 
Augustów, Kuriankę winien dotrzeć tego dnia ok. godz. 18.00 do Baranowicz. Tego samego dnia w związku z zamiarem przekroczenia granicy przez wojska niemieckie na granicy w miasteczku Filipów odbyły się rozmowy sowiecko-niemieckie. Ze strony sowieckiej brali w nich udział tymczasowy naczelnik oddziału operacyjnego płk Sieraszew i naczelnik wydziału politycznego korpusu, pułkowy komisarz Szyłow, ze strony niemieckiej rozmowy prowadził kpt. Ancewerg (Anzewerg?) ze sztabu generalnego. Ostatecznie sztab korpusu 2 października o godz. 10.00 wyjechał z Suwałk i o 20.00 był w Jeziorach ${ }^{47}$.

Spójrzmy na ten sam proces wraz z towarzyszacymi zjawiskami oczami polskich relacjonistów. Wkroczenie wojsk sowieckich do Suwałk odbyło się od strony południowej, czyli od Augustowa ${ }^{48}$. Wojska te zostały owacyjnie powitane przez suwalskich Żydów, co Polacy przyjęli ze zgorszeniem i niesmakiem $^{49}$. Na pewno nie było powitań w Sejnach (większość ludności żydowskiej uciekła wcześniej z tego miasteczka, głównie do Augustowa) ${ }^{50}$, ale odbyły się one w Raczkach. Zdaniem świadka „W Raczkach powitanie zgotowali miejscowi komuniści, ci sami, co przed wojna urządzali pochody na 1 maja, oni też zostali komitetem rewolucyjnym". Potem urządzono w tej miejscowości wiec antypolski z udziałem miejscowych komunistów. W okolicy zdarzyły się pojedyncze aresztowania, wojsko sowieckie zachowywało się poprawnie; relacjonista nie pamięta, by została tam zorganizowana milicja. Po przyjściu Niemców wygonili oni Żydów z Raczek w stronę linii demarkacyjnej na rzeczce Szczeberka, lecz Sowieci nie chcieli ich wpuszczać na swój teren. Żydzi stali bezradnie w rzece, a dookoła były podmokłe łakiisi. O tej patowej sytuacji na granicy i braku chęci przyjęcia do siebie Żydów wspomina ówczesny sekretarz Powiatowego Komitetu Komunistycznej Partii (bolszewików) Białorusi w Augustowie, Nikołaj Awchimowicz ${ }^{52}$. W pozostałych miejscowościach (głównie wsiach) nie udało się ustalić, czy miały miejsca powitania.

Wkroczenie wojsk sowieckich do Raczek nastapiło z końcem września via wieś Małe Raczki. Nadeszły one od strony Suwałk wieczorem. Był to oddział pancerny składający się z ok. 10 tankietek. Następnego dnia przez Małe

${ }^{47}$ RGWA, f. 35086, op. 1, d. 498, k. 30-35. Dodać należy, iż opisy działań jednostek sowieckich pisane są często chaotycznie, co może w efekcie prowadzić do błędnej rekonstrukcji. Dane o jednostkach i ich numeracja zidentyfikowane na podstawie Rozkazu Bojowego nr 01 Sztabu Frontu Białoruskiego Armii Czerwonej, w: Katyń..., t. I, dok. 3, s. 67 i n.

${ }^{48}$ Rel. Tadeusz Żochowski; rel. Stanisław Kolenkiewicz, ur. 1931, zam. Garwych Ruda, 12 km od Suwałk, z 5 VIII 2010; w zbiorach autora.

${ }^{49}$ Rel. Stanisław Kolenkiewicz; rel. Józef Morusiewicz, we wrześniu 1939 r. miał 13 lat, mieszkał we wsi Małe Raczki k. Raczek, z 27 XI 2010; w zbiorach autora.

${ }^{50}$ Rel. Jerzy Klimko, ur. 1925, mieszkaniec Sejn, z 10 VII 2010; w zbiorach autora.

${ }^{51}$ Rel. Józef Morusiewicz.

${ }^{52}$ N.J. Awchimowicz, Mój Augustów, w: Europa nieprowincjonalna. Przemiany na ziemiach wschodnich dawnej Rzeczypospolitej (Białoruś, Litwa, Łotwa, Ukraina, wschodnie pogranicze III Rzeczypospolitej Polskiej) w latach 1772-1999, red. K. Jasiewicz, Warszawa-Londyn 1999, s. 689 i n. 
Raczki przeszła piechota - źle ubrana: nieobrębione płaszcze, karabiny na sznurkach - i zaczęła obsadzać granicę w stronę Wiżajn ${ }^{53}$.

$\mathrm{Na}$ uszczelnianie granicy warto zwrócić uwagę, bowiem operacja nie miała specjalnego sensu z militarnego punktu widzenia. Zaobserwowana akcja najwyraźniej powodowana była chęcią wyłapania jak największej liczby potencjalnie niebezpiecznego elementu, czyli wojskowych służby czynnej, a zwłaszcza oficerów. Za taką hipotezą opowiadaja się Wojciech Materski i Natalia Lebiediewa, przytaczając dyrektywę Rady Wojennej Frontu Ukraińskiego z 19 IX 1939 r., nakazująca zamknięcie południowej b. granicy polskiej: „W żadnym wypadku nie dopuścić do wyjścia polskich żołnierzy i oficerów w Polski do Rumunii" ${ }^{54}$. Należy przypuszczać, że podobną dyrektywę - per analogiam - podjęła Rada Wojenna Frontu Białoruskiego, chociaż skuteczność tych przedsięwzięć była dość ograniczona, gdyż z osaczenia wyrwało się na Łotwę i Litwę ok. 18 tys. żołnierzy, a do Rumunii i Węgier - ponad 70 tys..$^{55}$

Ten ruch mógł być podyktowany zamysłem przyszłej zbrodni (katyńskiej), bo obawy przed odrodzeniem się Polski i polskiej armii, jak też prognozowanie dalszego rozwoju sytuacji można zaobserwować u wysokich przedstawicieli elity sowieckiej. Lew Mechlis, szef Głównego Zarządu Politycznego Armii Czerwonej, spotykając się z wybranymi pisarzami w celu m.in. omówienia ich udziału w opracowywaniu materiałów z kampanii polskiej, nad która strona sowiecka prowadziła gruntowne studia pod kątem wypływających z niej wniosków dla potrzeb armii, sytuację w Europie scharakteryzował następująco:

\begin{abstract}
Państwa boją się rozpętać wielką wojnę. Nie wyklucza się dziś możliwości kompromisu. Wariant pokojowy byłby korzystny: przedłużenie pokojowej przerwy, wygodna dla nas pozycja wobec wrogów, ochrona życia milionów. Wariant wojny: Niemcy robią ogólnie dobrą robotę nadszarpując brytyjskie Imperium. Jego rozbicie doprowadza do ogólnego krachu imperializmu - to jest jasne. Ogólnoświatowa wojna, a do tego mogą doprowadzić wydarzenia wciagnie wiele państw. Może wciagnąć i nas, bowiem robi się wszystko, żeby nam zaszkodzićs ${ }^{56}$.
\end{abstract}

Przypisał on także żołnierzom WP rolę konia trojańskiego, wreszcie jasno określił niebezpieczeństwa dla ZSRR wiążące się z dalszym życiem polskich oficerów. Mechlis uczestniczył w podejmowaniu decyzji wstępnej co do polskich jeńców przez Politbiuro WKP(b) i wspólnie z Berią opracował, a później zreferował koncepcję zagospodarowania zdobycznych zasobów ludzkich $\mathrm{WP}^{57}$.

${ }_{53}$ Rel. Józef Morusiewicz.

${ }^{54}$ Katyń..., t. I, s. 18: Wstęp (W. Materski, N. Lebiediewa) oraz dok. 14 - dyrektywa Rady Wojennej Frontu Ukraińskiego z 19 IX 1939, s. 87-88.

${ }^{55}$ Ibidem, Wstęp, s. 18.

${ }^{56}$ Rosyjskie Państwowe Archiwum Literatury i Sztuki w Moskwie (dalej: RPALiS), f. 1038, op. 1, d. 2076, k. 69.

57 Zob. decyzja Politbiura KC WKP(b) „O jeńcach wojennych” z 2 X 1939 r., w: Polscy jeńcy wojenni w ZSRR 1939-1941, oprac. W. Materski, Warszawa 1992, s. 21 i n. 
Pod data 11 XI 1939 r. pisarz Wsiewołod W. Wiszniewskij (Wiszniewski) w swoim dzienniku zrelacjonował przebieg spotkania grupy literatów z Mechlisem.

Masy robotnicze i chłopów - stwierdził gospodarz poufnego spotkania - można będzie pociąnąc $\mathrm{w}$ Polsce i Czechosłowacji hasłami wyzwolenia narodowego, konfiskaty ziemi itp. Jeńcy polscy zostali rozpuszczeni do domów. To są agitatorzy zdobycia ziemi i wolności. Oficerowie są w obozach. Nie należy ich wypuszczać, ponieważ będą to kadry dla formujacych się na Zachodzie legionów. Polacy mogą rozwinać się we Francji do 100 tysięcy [...]. U Ukraińców jest nadmiar uczuć nacjonalistycznych [...]. Sa trudności na wsis ${ }^{58}$.

Można też rozważyć inne motywy zabezpieczania granic. Obok powszechnej w ZSRS w całym okresie dziejów szpiegomanii alternatywną hipotezą - aczkolwiek nierealistyczną ze względu na złe stosunki polsko-litewskie i wzajemne animozje - mogła być obawa, że polskie jednostki, po uporządkowaniu szeregów, wypoczynku i dozbrojeniu, powróca, może wraz z Litwinami czy szerzej - Bałtami. Zważywszy na bardzo niechętne antysowieckie nastawienie społeczeństwa litewskiego i innych z tego regionu, zwłaszcza osób związanych z wojskiem, co można było zaobserwować potem już w lecie 1940 r., i chorobliwa podejrzliwość Sowietów w każdej dziedzinie, taki wariant też warto brać pod uwagę ${ }^{59}$. Watcpliwości jednak rozwiało samo życie. Wszyscy oficerowie

${ }^{58}$ RPALiS, f. 1038, op. 1, d. 2076, k. 69.

${ }^{59} \mathrm{Na}$ temat powstania z armii państw bałtyckich tzw. korpusów terytorialnych zob. RGWA, f. 37848, op. 1, d. 9, k. 1: Pismo zastępcy naczelnika Sztabu Nadbałtyckiego Okręgu Wojskowego, gen. majora Gusiewa nr 4/00164 z 20 VIII 1940 od zarządu politycznego Okręgu, okręgowych wydziałów i rodzajów wojsk z informacja, że na mocy dyrektyw Ludowego Komitetu Obrony ZSRR z 17 VIII 1940 nr 0/2/105022 rozkazuje się istniejacce armie narodowe Estonii, Litwy i Łotwy przekształcić w: 22 (Terytorialny) Korpus Strzelecki w Estońskiej SSR, 24 (Terytorialny) Korpus Strzelecki w Łotewskiej SSR, 29 (Terytorialny) Korpus Strzelecki w Litewskiej SSR, kadra dowódcza i polityczna tych korpusów ma pochodzić z zasobów RKKA tych narodowości i Rosjan. O stosunku społeczeństwa litewskiego i wojska litewskiego, z którego usiłowano stworzyć 29 Terytorialny Korpus Strzelecki Armii Czerwonej, zob. np.: ibidem, f. 1771, op. 2, d. 530, k. 4-15: Pismo nr 0141 Wojennego Komisarza 29 Korpusu Strzeleckiego, komisarza brygadowego Cariewa do sekretarza KC Komunistycznej Partii (bolszewików) Litwy, który informuje, że aż 424 oficerów różnych stopni należy zwolnić z Korpusu, bo się do tego wojska nie nadaja; ibidem, f. 1771, op. 2, d. 531, k. 2-6: Pismo Ludowego Komisarza Spraw Wewnętrznych LSSR, starszego majora bezpieczeństwa państwowego Guzjawiczusa „Informacja o polityczno-moralnym położeniu 29-go Terytorialnego Korpusu" ze stycznia 1941, z którego wynika m.in., że w sztabie Korpusu wykryto 107 osób określonych jako „wrogi element” (kułacy, handlowcy itd.), zaobserwowano liczne wypowiedzi antysowieckie wśród oficerów, w tym wyśmiewanie się z Armii Czerwonej. W 615 Pułku Artylerii był bunt 150 żołnierzy z powodu przysięgi wojskowej i zakazu chodzenia do kościoła, żądali oni utrzymania krzyży w koszarach zamiast symboli armii sowieckiej. O masowym zatruciu wodą (250 przypadków) w Wilnie w 29 Korpusie, co wyglądało na akt sabotażu, donosił Ludowy Komisarz Bezpieczeństwa Państwowego LSSR, st. major bezpieczeństwa państwowego Gładkow. Litewskie Archiwum Specjalne (Lietuvos Ypatingasis Archyvas [dalej: LYA]), f. K-1, op. 10, d. 345, Informacja specjalna 
i żołnierze WP, policja itd. na ogół dostali się po przekroczeniu granicy polsko-litewskiej do obozów internowania, gdzie nie zawsze byli dobrze traktowani ${ }^{60}$.

Tymczasem wydarzenia na Suwalszczyźnie po wkroczeniu Sowietów w narracji żydowskiej przedstawiały się następująco. Po kilku dniach od tego wydarzenia do miasta zaczęli powracać uciekinierzy, suwalscy Żydzi - odrapani, głodni i załamani. Wszystkich spotkał taki sam los. Gdzie nie poszli, tam zostali zbombardowani przez Niemców. Po powrocie zastali obrabowane domy i warsztaty pracy. Pojawiło się przekonanie, że lepiej było nie uciekać.

nr 11932 z 30 IV 1941, k. 68. Wcześniej wspomniany Guzjawiczus raportował do sekretarza KC KP(b) Litwy, że ok. 25-26 IX 1940 w 29 Pułku Artylerii, który formował się w składzie tego samego 29 Korpusu Terytorialnego, wśród litewskich żołnierzy panowały znaczące antysowieckie nastroje, obcinano pagony RKKA z mundurów. Ibidem, d. 1, „Nadzwyczajna informacja specjalna" Ludowego Komisarza Spraw Wewnętrznych LSSR, starszego majora bezpieczeństwa państwowego Guzjawiczusa do sekretarza KC KP(b) Litwy Snieczkusa z września 1940, k. 40. Chociaż widać tu różne niekonsekwencje, gdyż prawie w tym samym okresie sowieccy okupanci wnioskowali do (sowieckiego) litewskiego komitetu partii o nominacje na stanowiska dowódcze tegoż korpusu dla 8 generałów b. armii litewskiej. Litewskie Państwowe Archiwum Organizacji Społecznych (Lietuvos Valstybes Visuomenes Organizacijos Archyvas (dalej: LVVOA), f. 1771 [Wydział Wojskowy KC KP(b) Litwy], op. 1, d. 347, Pismo K-1/02111 zastępcy naczelnika Wydziału Kadr Nadbałtyciego Okręgu Wojskowego, Babienki do kierownika Wydziału Wojskowego KC KP(b) Litwy z 21 X 1940, k. nlb. Sytuacja na sowieckiej Litwie zmieniała się jak w kalejdoskopie, gdyż opór społeczny i zagrożenie stale jednak wzrastały, co zmusiło kierownictwo NKWD do wzmocnienia ochrony linii kolejowych, m.in. w tym celu przemieszczono 9 Dywizję Wojsk NKWD z Wilna do Kowna. Ibidem, op. 2, d. 533, Pismo Berii nr 1104/b do KC KP(b) Litwy z 11 IV 1941, k. nlb. Jednak podczas pierwszej wielkiej deportacji obywateli Litwy, która miała miejsce 15-17 VI 1940, wysiedlono „zaledwie” 12562 osoby, w tym „tylko” 221 b. oficerów armii litewskiej, carskiej i białych armii. LVVOA, f. 3377, op. 58, d. 916, k. 1. Nie najlepiej pod tym względem szły też sprawy w pozostałych Terytorialnych Korpusach Armii Czerwonej. Łotewskie Państwowe Archiwum Historyczne w Rydze (Latvijas Valsts Vēstures Arhívs), f. (łotew. fonda) 1474 (Armijas Stābs/ Sztab Armii), apr. (łotew. apraksta - opis), l. (lieta teczka) 675-756, 799; Łotewskie Państwowe Archiwum w Rydze (Latvijas Valsts Arhívs), f. 698 (Podomju Latvijas 24. Territorialais Strēlnieku Korpuss - 24 Terytorialny Korpus Strzelecki Radzieckiej Łotwy), apr. 1, 1. 1-18.

${ }^{60}$ Szeroko na ten temat pisze: W.K. Roman, Wobozach $i$ w konspiracji. Działalność niepodległościowa żotnierzy polskich na Litwie i Wileńszczyźnie, wrzesień 1939 - czerwiec 1941, Toruń 2004. Zob. eadem, Internowanie Polaków na Litwie w biuletynach Departamentu Bezpieczeństwa MSW Litwy (1939-1940), „Łambinowicki Rocznik Muzealny” 1998, nr 21; eadem, Internowanie żotnierzy polskich na Litwie wrzesien 1939 - lipiec 1940, „Przegląd Historyczno-Wojskowy" 2002, nr 2; eadem, Obozy dla internowanych żotnierzy polskich na Litwie IX 1939 - VII 1940 r. (w świetle źródet litewskich), „Łambinowicki Rocznik Muzealny” 1996, nr 19; P. Łossowski, Ksztattowanie się polityki litewskiej wobec obszarów przyłaczonych jesienia 1939 r., „Studia z Dziejów ZSRR i Europy Środkowej” 1981, t. XVII. Latem 1940 r., po aneksji republik bałtyckich, jako zdobyczny kontyngent zostali przejęci przez NKWD i przewiezieni do Kozielska (tzw. Kozielsk II) i Juchnowa, by ostatecznie trafić do miejscowości Panoj koło Murmańska. Zob. Katyń..., t. III: Losy ocalałych, Warszawa 2001, dok. 9, 12, 15, 17 i n. 
Zdaniem Żydów wejście Armii Czerwonej uspokoiło sytuację, zrobiło się bardziej stabilnie. Ale ta cisza nie trwała zbyt długo. Nadchodziły wieści z granicy sowiecko-niemieckiej. W szabat podczas święta Sukkot przywódcy sowieccy zwołali w parku miejskim zebranie, na którym obiecali, że Suwałki pozostaną pod władzą sowiecką. Jednak po kilku dniach dało się zauważyć, że Sowieci opuścili obszar Suwałk. Optymiści wierzyli, że Rosja sowiecka właczy Suwałki do Litwy, jak to zrobiła z Wilnem, ale ten optymizm podzielało niewielu. Strach przed dostaniem się w ręce „nazistów” wzrastał. Dlatego też każdego dnia setki Żydów uciekało z miasta w kierunku augustowskiej strony. Większość jednak została, bo pamiętała, w jakim stanie powrócili ci, którzy uciekli kilka tygodni temu z miasta, jak i co zastali ${ }^{61}$.

Oficjalne przekazanie miasta Niemcom nastapiło na moście przez rzekę Czarna Hańcza, będącym arterią miasta. Do Suwałk od strony Filipowa przyjechała kompania cyklistów ${ }^{62}$. Uciekinierzy żydowscy, oprócz Augustowa, zapewne pojawili się w innych miejscowościach północno-wschodniej Polski, np. wiemy o grupie takich bieżeńców, którzy osiedlili się w Sokółce i okolicach, nieopodal Białegostoku, mając tam nawet zaplecze w postaci krajanów - suwałczan ${ }^{63}$.

W polskich relacjach jest również mowa o rabunkach. Dokonywało je wojsko sowieckie, a łupem padały właśnie opuszczone mienie żydowskie oraz polskie mienie państwowe i samorządowe. „Po wkroczeniu - relacjonował Tadeusz Żochowski - wojska te potem grabiły miasto, budynki publiczne i opuszczone domy pożydowskie [m.in. widział jak wywożono meble i fortepiany], ograbiono gimnazjum ze wszystkich sprzętów, łącznie z wyposażeniem gabinetu dentystycznego" ${ }^{64}$. Wojska sowieckie okradły też opuszczone mieszkania w Sejnach (to w części dotyczyło mieszkań polskich wojskowych) ${ }^{65}$. Warto również zwrócić uwagę na fakt, iż duża grupa Żydów sejneńskich schroniła się w Augustowie i później - jeszcze przed zajęciem Sejn przez Niemców, a nawet w pierwszych dniach ich obecności - jeździła tam po meble i inne sprzęty, zwożąc je do Augustowa. Granica była wówczas bardzo nieszczelna

${ }^{61}$ J. Berlzon, op. cit., s. 601-602.

${ }^{62}$ Rel. Tadeusz Żochowski.

63 „Pieramoga. Organ Czasowaga Upraulienija gor[oda] Sakołka i pawieta [Organ Zarządu Tymczasowego miasta Sokółka i powiatu - w jęz. białoruskim]”, (Sokółka) 21 X 1939, nr 7, s. 3: pojawia się informacja o Kapłanie Aronie Jakowlewiczu, ur. 1907 w Suwałkach w rodzinie szewca, do 1922 uczył się w szkole powszechnej, potem pracował w piekarni. Aktywnie działał w ruchu rewolucyjnym, rodzinie zabroniono mieszkać w Suwałkach, więc przenieśli się do Dąbrowy Białostockiej, w 1933 otrzymał wyrok 5 lat więzienia, członek Tymczasowego Gminnego Komitetu Chłopskiego w Dąbrowie Białostockiej, a potem kandydat na deputowanego do Zgromadzenia Narodowego Zachodniej Białorusi z okręgu wyborczego nr 83 w m. Sokółka. „Pieramoga. Organ Czasowaga Upraulienija gor[oda] Sakołka i pawieta”, (Sokółka) 9 XII 1939, nr 25, s. 4: w powiecie i mieście Sokółka bieżeńcy otrzymuja pracę i mieszkania, są tu także bieżeńcy z Suwałk.

${ }^{64}$ Rel. Tadeusz Żochowski.

${ }^{65}$ Rel. Jerzy Klimko. 
i do czasu obsadzenia jej przez wojska pograniczne NKWD, co stało się późna jesienia, dało się ja łatwo przekroczyć. Dla owego procederu noszacego znamiona normalnego rabunku korzystano nawet $\mathrm{z}$ ciężarówek sowieckich, co przy skorumpowaniu „wyzwolicieli” trudno uznać za coś wyjątkowego ${ }^{66}$. Poważna reperkusją tego zjawiska mogła być mylna opinia, iż rabunku mienia pożydowskiego dokonała ludność polska lub Niemcy, chociaż takich przypadków z pewnością nie należy wykluczać.

Na Suwalszczyźnie - traktując jej sowiecką okupację jako studium przypadku - można zaobserwować w czystej krystalicznej postaci kilka ważnych zjawisk, które pozwalaja lepiej zrozumieć okupację sowiecką Kresów Wschodnich 1939-1941 i towarzyszące jej stosunki międzyetniczne ${ }^{67}$. Suwałki (zwłaszcza) i Suwalszczyzna w porównaniu z Kresami Wschodnimi są terenem dość jednolitym etnicznie. Przed 1939 r. społeczność miasta - korzystając z ułomnego kryterium używanego języka - składała się praktycznie z dwóch nacji: Polaków (71,0\%) i Żydów (26,3\%); pozostali znajdowali się na marginesie (osoby narodowości rosyjskiej - 1,8\%, niemieckiej - 0,5\%, ukraińskiej - 0,3\%; 20 osób podawało się za Litwinów, 8 - za Białorusinów, 13 osób nie wskazało swojej narodowości) ${ }^{68}$. W odróżnieniu od miast i miasteczek Kresów, gdzie doszło do antypolskich wystapień z udziałem niemal wszystkich mniejszości (z wyjątkiem Tatarów, Ormian i Karaimów), Suwałki ukazuja zderzenie się polsko-żydowskich kontaktów w postaci czystej. Ten obszar nie był też badany pod tym kątem, a krótkotrwałość zjawiska zniwelowanego natychmiastową okrutną okupacją niemiecką nie pozwoliła ani na wytworzenie literatury przedmiotu, ani - co dużo ważniejsze - zasobu relacyjnego, który kształtuje w głównej mierze nasze wyobrażenia o czasie minionym. Okupacja sowiecka - co moim zdaniem miało znaczenie - była krótkotrwała i bez drastycznych przejawów.

Przechodząc do analizy przypadku suwalskiego, w celu wychwycenia rozleglejszych tendencji zwróciłbym uwagę na kilka rzeczy. Zacznijmy od samego postrzegania faktów. I tak w Archiwum Wschodnim spotykamy np. relacje z Kresów, z których jedne odnotowują dane zjawiska, a inne ich wcale nie zauważają. Badając obszar Suwalszczyzny i poszukując świadków wydarzeń sprzed kilkudziesięciu lat, natrafiłem na taką bardzo znamienną parę relacjonistów. Obaj mieszkali w tej samej wsi - Gawrych Rudzie oddalonej od Suwałk o ok. $12 \mathrm{~km} \mathrm{w}$ kierunku południowo-wschodnim, byli mniej więcej w tym samym wieku, mieli podobne wykształcenie (a ściślej byli wówczas dorastającymi dziećmi), ich domy rodzinne znajdowały się niemal obok siebie

\footnotetext{
${ }^{66}$ Ibidem.

${ }^{67}$ Zob. olbrzymie zbiory relacji w AW w układzie powiatowym, szczegółowo opisujące różne zjawiska patologiczne: od powitań wojsk sowieckich i działalności różnych milicji po rabunki mienia, udział w sfałszowanych wyborach itd. Przestudiowałem te wszystkie relacje.

${ }^{68}$ A. Matusiewicz, op. cit., s. 322.
} 
(w odległości ok. $200 \mathrm{~m}$ ), jeden z nich był Polakiem, drugi - z pochodzenia Ukraińcem $^{69}$. Jeśli $\mathrm{w}$ polskim domu ze zgorszeniem mówiono o postawach suwalskich Żydów w związku z pojawieniem się armii sowieckiej, tak u nieodległych sąsiadów nawet nie zauważono obecności sowieckiej w Suwałkach. Mój rozmówca wykazał ogromne zdziwienie, dowiadując się ode mnie, że kilkadziesiąt lat temu w pobliskim mieście przez kilkanaście dni znajdowała się duża grupa wojska sowieckiego, a cała wielka jednostka kwaterowała we wsi Sobolewo, odległej od Gawrych Rudy o kilka kilometrów. W tej ostatniej wsi, Gawrych Rudzie, mieszkało kilkunastu Ukraińców - emigrantów, przeważnie byłych petlurowców, pożenionych z Polkami i posiadających stałe zatrudnienie $\mathrm{w}$ pobliskim tartaku w Płocicznie. I tu kolejna ciekawostka wszyscy oni poszli na bardzo aktywną współpracę z okupantem niemieckim i dali się bardzo mocno we znaki miejscowym chłopom ${ }^{70}$. I jeszcze jedna uwaga - najzagorzalszy ukraiński kolaborant z tej wsi nie został zlinczowany. Gdy poprosił o litość, wybaczono mu jego przewinienia ${ }^{71}$. Inna anomalia relacjonista z Suwałk nic nie słyszał o żydowskich powitaniach, podczas gdy dwaj inni spoza miasta o nich wiedzieli ${ }^{72}$.

Również obywatele Suwałk pochodzenia niemieckiego nie popisali się swoją lojalnościa, najbardziej aktywni w obawie przed zemstą czy odpowiedzialnością uciekli przed 1 IX 1939 r. Ta kategoria osób, w tym zapewne wielu być może zupełnie niewinnych, w związku z wojna została później internowana przez władze polskie i wywieziona do Berezy Kartuskiej, część z nich zmarła w drodze i na miejscu w obozie (okoliczności nieznane), a nieliczni wrócili do domów po zakończeniu kampanii wrześniowej ${ }^{73}$.

Byłbym przeciwny przypisywaniu tych postaw patologicznych (i wspomnianych Ukraińców, i suwalskich Żydów, i Niemców) złej polityce wobec mniejszości narodowych w Polsce międzywojennej i jakimś szczególnym szykanom ze strony Polaków. W moim przekonaniu decydować mogły dwa względy (ale to ocena subiektywna): ówczesny model państw jako narodowych (też nie demonizowałbym tej idei), który siłą rzeczy wskazywał bądź uprzywilejowywał główny naród, zupełnie odmienny ogląd i wrażliwość mniejszości narodowych oraz izolacjonizm i nadwrażliwość tych mniejszości, co oczywiście nikogo nie powinno rozgrzeszać z popełnionych podłości po obu stronach opisywanych stosunków. (Ocena podłości ludzkich nie jest przedmiotem mojej analizy i w tym zakresie nie widzę specjalnych perspektyw dla osiagnięcia consensusu nawet $\mathrm{w}$ środowisku naukowym).

\footnotetext{
${ }^{69}$ Rel. Stanisław Kolenkiewicz; rel. Jan Kumiszcza, ur. 1930, zam. Gawrych Ruda, z 3 VII 2010; w zbiorach autora.

70 Rel. anonimowa mieszkańca wsi Gawrych Ruda, ur. 1920, z 4 VII 2010; osoba udzieliła informacji pod warunkiem niepublikowania jej nazwiska, w zbiorach autora.

${ }^{71}$ Ibidem.

${ }^{72}$ Rel. Tadeusz Żochowski, rel. Stanisław Kolenkiewicz, rel. Józef Morusiewicz.

${ }^{73}$ K. Skłodowski, Wojna i okupacja..., s. 444 i n.
} 
Obserwując wspomniane cztery nacje (Żydzi, Ukraińcy, Niemcy, Polacy) na terytorium Suwałk i Suwalszczyzny, zaryzykowałbym twierdzenie, że być może decydujący faktor zewnętrzny kształtujący zachowania ich przedstawicieli brał się - po części - z jakiejś idei, nazwijmy umownie „mesjańskiej”, u Polaków dodatkowo wzmocnionej poczuciem obrony z trudem zdobytej niepodległości, chociaż każda nacja posiada również jakieś swoje „wspomagania”. Tu też będzie miało znaczenie istnienie modelu państwa narodowego. I tak Żydzi, w owej epoce społeczność bardzo religijna i zachowawcza, zapewne kierowali się wskazaniami swojego prawa religijnego - halachy.

Bóg nałożył na Żydów wzniosły obowiązek - czytamy to prawo w opracowaniu rabina Zewa Greenwalda - Nie tylko musimy przybliżać się do Wszechmocnego zachowując Jego 613 micwot [przykazań], musimy także nieść światło oraz duchowe natchnienie wszystkim innym narodom. $\mathrm{Z}$ uwagi na naszą własną duchową zasługę oraz powołanie, nie możemy pozwolić, by przyciagały nas zwyczaje innych narodów [...]. Żyd powinien zachowywać się oraz prowadzić wszelkie swoje sprawy w sposób, który świadczy o tym, iż należy on do narodu Boga oraz że jako członek tej wspólnoty wiernie dąży do wypełnienia woli swojego Stwórcy ${ }^{74}$.

Ukraińców, zwłaszcza z przeszłością petlurowska, mogła zapewne zżerać tęsknota za swoim państwem narodowym, o które przecież osobiście walczyli. Niemcy mieli okres zauroczenia narodowym socjalizmem i jego wizja budowania innego świata kreowanego, wówczas jeszcze nie tak groźnie, przez wizje Adolfa Hitlera. Wreszcie Polacy, naród tradycyjnie przywiązany do katolicyzmu, zapewne uważali, iż bycie „przedmurzem chrześcijaństwa” należy do ich dozgonnego obowiązku i ich państwa.

Pewne patologiczne zachowania, jak witanie wrogich wojsk, w świetle zdobytych informacji nie przełożyły się na wrogość Polaków do tych osób. Inny relacjonista wspominał, że jego rodzina przed wojną prowadziła jakieś wspólne interesy z suwalskimi Żydami (przykładów takiej kooperacji ekonomicznej było więcej) i po rozpoczęciu się gehenny Żydów pod zaborem niemieckim, mimo pamięci o powitaniach, zaproponowała pomoc w przetrwaniu, która nie została przyjęta $\mathrm{w}$ związku z zamysłami przedarcia się na sowiecką stronę względnie litewską w celu dalszej emigracji (losy tej rodziny pozostają nieznane) $)^{75}$. Być może - ale to bardzo ryzykowna hipoteza - na pogorszenie relacji międzyetnicznych miały wpływ długotrwałość i powtarzalność jakichś zjawisk patologicznych. Czyli np. nie liczył się tak bardzo sam fakt powstania milicji żydowskiej, ile bardziej jej działania represyjne i czas ich występowania.

Uważam, iż poszukiwanie prawdy jest obowiązkiem każdego badacza, a jakiekolwiek stygmatyzowanie stoi w sprzeczności z etosem nauki. Być może

${ }^{74}$ Z. Greenwald, Bramy Halachy. Religijne prawo żydowskie. Kicur Szulchan Aruch dla wspótczesności, red. rabin S. Pecaric, Kraków 2005, s. 37.

75 Rel. anonimowa II, relacjonista ze wsi Gawrych Ruda, ur. 1921; zgodził się na rozmowę pod warunkiem nieujawniania nazwiska, z 5 VII 2010, w zbiorach autora. 
ten tekst otworzy dyskusję na tematy bardzo złożone i trudne, eliminując w rezultacie różne stereotypy.

Inne ciekawe zjawisko zaobserwowane na Suwalszczyźnie to nieustanny ruch wojsk sowieckich. Nie można w nim dopatrzeć się żadnych sensownych przesłanek militarnych. Nie ma tam bowiem żadnych zorganizowanych polskich jednostek wojskowych, nie toczą się walki. Marszruty, mimo złych dróg, sa zbyt krótkie, aby zmęczyć. Sowieckie wojsko nie potrzebuje zmienników ani czasu na wypoczynek i uzupełnienia. Wszystko to sprawia wrażenie działań trochę bez sensu, chyba że chodzi o propagandowe wrażenie, że Sowieci sa wszędzie i przez cały czas. Nawet jeśli ich w tej chwili nie widać, to zaraz moga się pojawić. Ten sam wielki ruch widzimy na Kresach Wschodnich, choć tam bywa on uzasadniony jakimiś potyczkami, pościgiem za rozbitymi pododdziałami WP, koniecznością wypoczynku i zmiany na pozycjach. To zjawisko wyjaśnia nam liczne rozbieżności w relacjach, w których pojawiają się różne daty wkroczenia Sowietów, a także różne kierunki, z których przybywaja.

Blokowanie granicy jako jedna z pierwszych czynności wojsk sowieckich przybywajacych do obszarów przygranicznych też nie ma uzasadnienia wojskowego, lecz wynika $\mathrm{z}$ tego, iż chodzi nie tylko o podbój obszaru, ale też ludzi. Oni sa traktowani jako przyszła niewolnicza zdobyczna siła robocza. Być może chodzi też o to, by nikt się nie wydostawał, bo mógłby za granica podjąć jakąś akcję antysowiecką o charakterze militarnym (tworzenie wojska), politycznym (tworzenie jakiś namiastek organów państwa lub przedstawicielstw państwa polskiego) itp. Jednak osobiście widzę ten ruch w perspektywie zbrodni katyńskiej. Przypuszczam, że Stalinowi od początku chodziło o trwałe zniszczenie Polski, co wedle jego metod mogło odbyć się poprzez fizyczną eksterminację elit/ potencjalnych elit i całego wartościowego polskiego elementu ze wszystkich klas i warstw, stąd na przykład wyjątkowo trzebiona była populacja uczestników wojny polsko-sowieckiej 1920 r. (element szczególnie patriotyczny). Wszystko to nabiera sensu zwłaszcza w konfrontacji z rozważaniami Jörga Baberowskiego analizującego wyjątkowo wnikliwie patologiczną osobowość sowieckiego dyktatora i jego mordercze instynkty ${ }^{76}$.

Obecność Sowietów równoznaczna jest z szerokim rabunkiem mienia przez nich, a także przez wszystkich chętnych, którzy z tego powodu nie mają na ogół żadnych przykrości. Ten rabunek postrzegałbym jako wyraz zapobiegliwości (charakterystyczny dla ludzi wychowanych w systemie permanentnych niedoborów), ale też brak pewności co do dalszej przynależności podbitych ziem, bo zwróćmy uwagę, iż Kresy Wschodnie zostały najpierw doszczętnie ograbione (zrobili to Sowieci wspólnie z miejscową hołota), a potem - po właczeniu ich w skład terytorium ZSRS - dokonywano tam różnych inwestycji, na ogół w sferze infrastruktury (drogi, koleje, ale także osuszenie bagien

\footnotetext{
${ }^{76}$ J. Baberowski, Stalin. Terror absolutny, Warszawa 2014, passim.
} 
Polesia), głównie z myślą czerpania z nich większych korzyści, jak również biorac pod uwagę przyszłą wojnę z Niemcami.

W naszej historiografii w dialogu naukowym o Kresach panuje przekonanie, że pojawienie się Armii Czerwonej, a po niej aparatu sowieckiego działało jako katalizator na miejscowe stosunki narodowościowe i społeczne i wszystkie zło, jakie się tam wydarzyło, ma niejako swoje praźródło w ustroju ZSRS ${ }^{77}$. Wydaje się jednak, że można sformułować zupełnie inną alternatywną hipotezę. W moim przekonaniu każdy zaborca/ najeźdźca występujący w roli obrońcy uciskanych, dyskretnie stosujacy terror (Dlaczego aresztowania, deportacje, a nawet egzekucje Sowieci wykonywali noca? Właśnie dlatego) i racjonalnie wykorzystujący czynnik militarny (Czyli tylko wtedy, gdy nie było wyjścia, zob. np. deklaracje ich wojsk, że przychodzą Polsce z pomoca, co ułatwiało opanowywanie terenu bez walki), wywołałby ten sam efekt.

Niemcy zdecydowanie nie poszukiwali porozumienia z miejscową ludnościa, przez co stosunek do nich nigdy nie stał się ambiwalentny - oni zawsze byli wrogiem i nikt co do tego nie miał wattpliwości. Natomiast Sowieci występowali w roli wyzwoliciela i sprawiedliwego sędziego; oni nie przychodzili z wrogimi zamiarami, tylko chcieli nam pomóc. Byli de facto przyjaciółmi.

Rząd Sowiecki polecił wobec powyższych okoliczności [upadku państwa polskiego] Naczelnemu Dowództwu Armii Czerwonej - czytamy w nocie Mołotowa doręczonej ambasadorowi II RP w Moskwie, W. Grzybowskiemu - aby nakazało wojskom przekroczyć granicę i wziąć pod swoją opiekę życie i mienie ludności zachodniej Ukrainy i zachodniej Białorusi. Rząd sowiecki zamierza równocześnie podjać wszelkie środki majace na celu uwolnienie narodu polskiego od nieszczęsnej wojny, w którą wepchnęli go nierozsądni przywódcy, i umożliwienie mu życia w pokoju ${ }^{78}$.

„Nie jesteśmy zaborcami, lecz wyzwolicielami” - czytamy w odezwie dowództwa Armii Czerwonej z 17 IX $1939^{79}$.

I takie działania moga, zwłaszcza z pomoca tzw. V kolumny i propagandy, trafić na podatny grunt, zwłaszcza u każdej mniejszości, bowiem ich immanentną cechą wada jest stałe poczucie krzywdy i niesprawiedliwości. Nawet w partyjnej gazecie typowa i prawdziwa wydaje się dla tego toku myślenia cytowana wypowiedź robotnika, Żyda N. Kopa: „Promień słońca ze Wschodu

${ }^{77}$ Zob. np.: K. Jasiewicz, Zagłada polskich Kresów. Ziemiaństwo polskie na Kresach Pótnocno-Wschodnich Rzeczypospolitej pod okupacja sowieckq 1939-1941. Studium z dziejów zagtady dawnego narodu politycznego, Warszawa 1997; idem, Pierwsi po diable. Elity sowieckie w okupowanej Polsce 1939-1941, Warszawa 2003; A. Głowacki, Sowieci wobec Polaków na ziemiach wschodnich II Rzeczypospolitej 1939-1941, Łódź 1998; R. Szawłowski, Wojna polsko-sowiecka 1939, Warszawa 1996; M. Wierzbicki, Polacy i Białorusini w zaborze sowieckim. Stosunki polsko-białoruskie na ziemiach pótnocno-wschodnich II Rzeczypospolitej pod okupacja sowiecka 1939-1941, Warszawa 2000.

${ }_{78}$ Agresja sowiecka na Polskę..., t. I, dok. 82, s. 156.

${ }^{79}$ Ibidem, dok. 88, s. 164. 
oświetlił nasze życie, uczynił je szczęśliwym i radosnym" ${ }^{80}$. Tysiące takich świadectw dostarczaja polskie zbiory, choć przypisują im jednoznacznie negatywną ocenę. Wspominają one oczywiście także o patologicznych postawach innych mniejszości, a nawet samych Polaków ${ }^{81}$. Raczej za bardzo nietypowa i osamotnioną wypowiedź, niestety z pogranicza zdrady i jakiejś zadry do polskiej państwowości, należy uznać słowa Jana Turlejskiego, wypowiedziane w Łomży: „Jestem Polakiem, lecz zawsze nienawidziłem i nienawidzę byłego państwa Polskiego [...] Oddałbym wszystko, żeby zniszczyć to państwo" 82 .

Jednak cała sztuka polega na tym, by się nie dać zwieść pozorom. Na każdą postawę patologiczną można znaleźć stosowny przykład i jakoś próbować ją wytłumaczyć. Rzecz jednak w proporcjach i liczbach. Trzy patologiczne przypadki nie tworzą zjawiska, ale trzy tysiące mają inną wymowę i pokazuja, że coś się wydarzyło. Trzeba mieć odwagę, by to zauważyć. Trzeba też mieć na uwadze, że w dziedzinie etyki czy moralności kompromisy nie sa raczej możliwe, a tam gdzie kompromisy nie są możliwe, dyskurs traci sens.

\section{Streszczenie}

Okupacyjno-wojenna historia Suwałk i Suwalszczyzny kojarzona jest wyłącznie z najazdem niemieckim i późniejszą przynależnością tego obszaru do III Rzeszy. Tymczasem pierwotnie obszar ten znalazł się, w krótkim okresie od 24 IX do 6 X 1939 r., pod okupacją sowiecką na mocy paktu Ribbentrop-Mołotow. Na Suwalszczyźnie - traktując jej sowiecką okupację jako studium przypadku - można zaobserwować w krystalicznej postaci kilka ważnych zjawisk, które pozwalają lepiej zrozumieć okupację sowiecką całych Kresów Wschodnich 1939-1941 i towarzyszące jej stosunki międzyetniczne. Obserwując cztery główne nacje (Żydzi, Ukraińcy, Niemcy, Polacy), można zaryzykować twierdzenie, że decydujący czynnik zewnętrzny kształtujący zachowania ich przedstawicieli wziął się - po części - z jakiejś idei, nazwijmy umownie „mesjańskiej”, u Polaków dodatkowo wzmocnionej poczuciem obrony z trudem zdobytej niepodległości, chociaż każda nacja ma również jakieś swoje „wspomagania" oraz pewnego znaczenia nabierze tu istnienie modelu państwa narodowego. I tak Żydzi, w owej epoce społeczność bardzo religijna i zachowawcza, zapewne kierowali się wskazaniami swojego prawa religijnego - halachy. Ukraińców, zwłaszcza z przeszłością petlurowska, mogła zapewne zżerać tęsknota za swoim państwem narodowym. Niemcy mieli okres zauroczenia narodowym socjalizmem i jego wizją budowania innego świata kreowanego, wówczas jeszcze nie tak groźnie, przez wizje Adolfa Hitlera. Wreszcie Polacy, naród tradycyjnie przywiązany do katolicyzmu, zapewne uważali, iż bycie „przedmurzem chrześcijaństwa” należy do ich dozgonnego obowiązku.

80 „Zapadnij Wodnik. Organ Polit-Otdieła Uprawlenija Zapadnogo Riecznogo Parochodstwa i Backomrecza", (Pińsk) 21 X 1940, nr 6.

${ }^{81}$ Zob. liczne relacje w zbiorach AW.

82 „Zapadnaja magistral'. Organ politotdieła i uprawlenija Biełostockoj żeleznoj dorogi”, (Białystok) 4 III 1940, nr 12, s. 4. 


\section{An Unknown Episode of the Second World War. The Soviet Occupation of Suwałki Region 24 September - 6 October 1939 as a case study}

The war and occupation history of Suwałki and Suwałki region is associated almost exclusively with the German aggression and the later annexation of this territory to the Third Reich. Initially, however, within two weeks between 24 September and 6 October 1939, the area found itself under the Soviet occupation, according to the provisions of the Ribbentrop-Molotov Pact of 23 August 1939. When treating it as a case study, it is possible to observe in Suwałki region several important phenomena in their pure form, which allow to better understand the Soviet occupation in the whole region of the so-called Polish Eastern Frontiers in 1939-41 and the accompanying ethnic relations.

The article describes military operations of the Soviets and attitudes of the local population, diverse both in terms of ethnicity and religion. At the beginning of the war there were no conflicts in the analysed region, characteristic of the Polish Eastern Frontiers, which allows us to conduct research with no later influences resulting from the long Soviet occupation. The observation of four main nationalities (Jews, Ukrainians, Germans, and Poles) justifies an opinion that, probably, the decisive external factor influencing their attitudes was related to an idea which could be called "Messianic", as well as the model of nation state. There were some additional incentives, too; for the Jews, for example, at that time deeply religious and conservative community, it probably was Halakha - the collective body of Jewish religious laws; for the Ukrainians, especially associated with former Petliura's Ukraine, it could have been a feeling of nostalgia for their nation state. The Germans were going through the stage of infatuation with national socialism and its visions of a new world created by - not so threatening at that time - Adolph Hitler's dreams. And for the deeply Catholic Poles, apart from the feeling of necessity to defend newly regained independence, it was also the feeling of duty to act as a traditional "bulwark of Christendom".

\section{Bibliografia}

Agresja sowiecka na Polskę w świetle dokumentów 17 września 1939, t. I: Geneza i skutki agresji, wybór i oprac. Cz. Grzelak, S. Jaczyński, E. Kozłowski, Warszawa 1994.

Armia Czerwona $w$ latach 1940-1941 (Materiaty z posiedzenia Gtównej Rady Wojennej i wyższej kadry dowódczej Armii Czerwonej w dniach 23-31 grudnia 1940 roku), oprac. J.R. Budziński, Cz. Grzelak, Z. Matuszak, Warszawa 2007.

Baberowski J., Stalin. Terror absolutny, Warszawa 2014.

Buczyński S., Suwalszczyzna 1939-1944, Warszawa 1991.

Dokumienty wnieszniej politiki 1940 - 22 ijunja 1941, red. G.E. Mamiedow i in., Moskwa 1998. Europa nieprowincjonalna. Przemiany na ziemiach wschodnich dawnej Rzeczypospolitej (Białoruś, Litwa, Łotwa, Ukraina, wschodnie pogranicze III Rzeczypospolitej Polskiej) w latach 1772-1999, red. K. Jasiewicz, Warszawa-Londyn 1999.

Greenwald Z., Bramy Halachy. Religijne prawo żydowskie. Kicur Szulchan Aruch dla wspótczesności, red. rabin S. Pecaric, Kraków 2005.

Grzelak Cz., Armia Stalina 1939-1941. Zbrojne ramię polityki ZSRS, Kielce-Warszawa 2010. Jasiewicz K., Militarne $i$ ekonomiczne aspekty $w$ budowie $i$ eksploatacji dróg żelaznych w Królestwie Polskim w latach 1835-1914, „Studia Historyczne” R. XXIII, 1980, z. 2 (89).

Jasiewicz K., Wykorzystanie kolei do celów militarnych (1830-1914), „Eksploatacja Kolei” R. V (XXIX), 1982, nr 4.

Jisker-buch Suwalk un di arumike sztetlech: Baklerawe, Wiżan, Jelinewe, Sejni, Punsk, Pszerasle, Filipowe, Krasnepolie, Rack, ed. B. Kohen, New York 1961. 
Katyń. Dokumenty zbrodni, red. i oprac. nauk. W. Materski. B. Woszczyński, N.S. Lebiediewa i in., t. I: Jeńcy nie wypowiedzianej wojny, t. III: Losy ocalałych, Warszawa 1995-2001. Kryska-Karski T., Żurakowski S., Generałowie Polski niepodległej, Warszawa 1991.

Organy gosudarstwiennoj biezopasnosti SSSR $w$ Wielikoj Otieczestwiennoj wojnie, t. I: Nakanunie, Kniga pierwaja (nojabr' 1938 g. - diekabr' 1940 g.) i Kniga wtoraja (1 janwarja - 21 ijunja 1941 g.), Moskwa 1995.

Polscy jeńcy wojenni w ZSRR 1939-1941, oprac. W. Materski, Warszawa 1992.

Roman W.K., W obozach i w konspiracji. Działalność niepodlegtościowa żotnierzy polskich na Litwie i Wileńszczyźnie, wrzesień 1939 - czerwiec 1941, Toruń 2004.

Sefer kehilat Suvalk u-benotehah (Jewish community book Suwalk and vicinity), ed. Y. Alroi, Y. Chrust, Tel Aviv 1989.

Skłodowski K., Stużba duszpasterska w garnizonie Suwatki 1921-1939, „Rocznik Augustowsko-Suwalski” 2012, t. XII.

Suwałki. Miasto nad Czarna Hańcza, red. J. Kopciał, Suwałki 2005.

Tucholski J., Mord w Katyniu. Kozielsk-Ostaszków-Starobielsk - lista ofiar, Warszawa 1991.

Wojennaja razwiedka informirujet. Dokumienty razwieduprawlenija Krasnoj Armii, janwar' 1939 - ijun’ 1941, oprac. W.A. Gawriłow, Moskwa 2008.

Bi o g r a m: Krzysztof Jasiewicz - prof. zw. dr hab., prof. mianowany w Instytucie Studiów Politycznych PAN. Opublikował m.in.: Lista strat ziemiaństwa polskiego 1939-1956, t. I-II (1995); Zagtada polskich Kresów. Ziemiaństwo polskie na Kresach Pótnocno-Wschodnich Rzeczypospolitej pod okupacja sowiecka 1939-1941 (1997); Pierwsi po diable. Elity sowieckie w okupowanej Polsce 1939-1941 (2001); Rzeczywistość sowiecka 1939-1941 w świadectwach polskich Żydów (2009); Oni. Okupacyjny aparat sowiecki na Kresach Pótnocno-Wschodnich w latach 1939-1941 (2015). Redaktor prac zbiorowych: Europa nieprowincjonalna. Przemiany na ziemiach wschodnich dawnej Rzeczypospolitej (Białoruś, Litwa, Eotwa, Ukraina, wschodnie pogranicze III Rzeczypospolitej Polskiej) 1772-1999 (1999); Tygiel narodów. Stosunki społeczne i etniczne na dawnych ziemiach wschodnich Rzeczypospolitej 1939-1953 (2002); Świat NIEpożegnany. Żydzi na dawnych ziemiach wschodnich Rzeczypospolitej $w$ XVIII-XX wieku (2004). Zainteresowania: historia Kresów Wschodnich 1939-1956, imperium sowieckie 1917-1991, stosunki polsko-żydowskie, dzieje Żydów. E-mail: kjasi@isppan.waw.pl. 